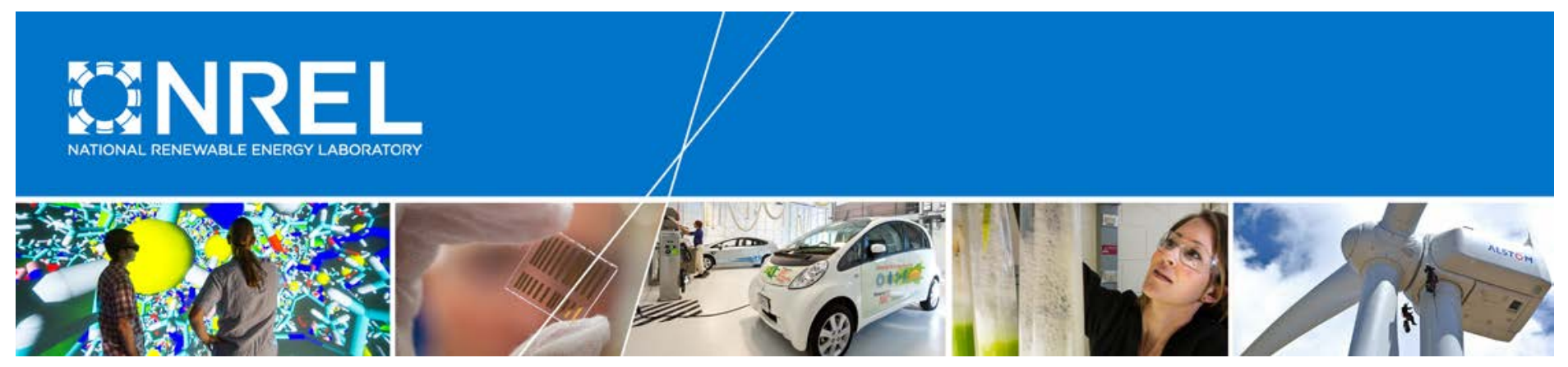

\title{
Techno-Economic Renewable Energy Potential on Tribal Lands
}

Anelia Milbrandt, Donna Heimiller, and Paul Schwabe National Renewable Energy Laboratory

NREL is a national laboratory of the U.S. Department of Energy Office of Energy Efficiency \& Renewable Energy Operated by the Alliance for Sustainable Energy, LLC

This report is available at no cost from the National Renewable Energy Laboratory (NREL) at www.nrel.gov/publications.

Technical Report

NREL/TP-6A20-70807

July 2018 


\title{
Techno-Economic Renewable Energy Potential on Tribal Lands
}

\author{
Anelia Milbrandt, Donna Heimiller, \\ and Paul Schwabe \\ National Renewable Energy Laboratory
}

\section{Suggested Citation}

Milbrandt, Anelia, Donna Heimiller, and Paul Schwabe. 2018. TechnoEconomic Renewable Energy Potential on Tribal Lands. Golden, CO: National Renewable Energy Laboratory. NREL/TP-6A20-70807. www.nrel.gov/docs/fy180sti/70807.pdf.

NREL is a national laboratory of the U.S. Department of Energy

Office of Energy Efficiency \& Renewable Energy

Operated by the Alliance for Sustainable Energy, LLC

This report is available at no cost from the National Renewable Energy Laboratory (NREL) at www.nrel.gov/publications.

National Renewable Energy Laboratory 15013 Denver West Parkway

Golden, CO 80401

303-275-3000 • www.nrel.gov

\section{Technical Report}

NREL/TP-6A20-70807

July 2018

Contract No. DE-AC36-08GO28308 


\section{NOTICE}

This work was authored by the National Renewable Energy Laboratory, operated by Alliance for Sustainable Energy, LLC, for the U.S. Department of Energy (DOE) under Contract No. DE-AC36-08G028308. Funding provided by the U.S. Department of Energy Office of Indian Energy Policy and Programs. The views expressed in the article do not necessarily represent the views of the DOE or the U.S. Government.

This report is available at no cost from the National Renewable Energy Laboratory (NREL) at www.nrel.gov/publications.

U.S. Department of Energy (DOE) reports produced after 1991 and a growing number of pre-1991 documents are available free via www.OSTI.gov.

Cover Photos by Dennis Schroeder: (left to right) NREL 26173, NREL 18302, NREL 19758, NREL 29642, NREL 19795.

NREL prints on paper that contains recycled content. 


\section{Acknowledgments}

This work was funded by the U.S. Department of Energy Office of Indian Energy Policy and Programs. We especially thank Lizana Pierce, Project Officer and Deployment Supervisor, for her support and direction throughout this project. We thank Elizabeth Doris and Sherry Stout from the National Renewable Energy Laboratory (NREL) for their leadership, guidance, and feedback on this work. We acknowledge the geospatial support provided by Meghan Mooney, Galen Maclaurin, and Evan Rosenlieb from NREL. We also thank our external and internal reviewers: Austin Brown, Executive Director, University of California, Davis, Policy Institute for Energy, Environment, and the Economy; Jana Ganion, Sustainability and Government Affairs Director, Blue Lake Rancheria, California; and Anthony Lopez, David Hurlbut, and Philipp Beiter from NREL.

This study serves as a reference for the renewable energy resource potential data used in the Tribal Energy Atlas available at https://maps.nrel.gov/tribal-energy-atlas. The Atlas is an interactive geospatial application that allows users to view resources, infrastructure, demographic, and other information relevant to energy resources on tribal lands, as well as query the data and perform simple analyses. Although this report is specific to renewable energy data, the Atlas also includes conventional infrastructure and market information. Additional information about the Atlas is available in Appendix B of this report.

\section{Disclaimer}

The views and opinions of the authors expressed herein do not necessarily state or reflect those of the United States Government or any agency thereof. Neither the United States Government nor any agency thereof, nor any of their employees, makes any warranty, expressed or implied, or assumes any legal liability or responsibility for the accuracy, completeness, or usefulness of any information, apparatus, product, or process disclosed, or represents that its use would not infringe privately owned rights. 


\section{Nomenclature and List of Acronyms}

$\begin{array}{ll}\text { ATB } & \text { Annual Technology Baseline } \\ \text { CSP } & \text { concentrating solar power } \\ \text { EIA } & \text { U.S. Energy Information Administration } \\ \text { GW } & \text { gigawatt } \\ \text { GWh } & \text { gigawatt-hour } \\ \text { h } & \text { hour } \\ \text { km } & \text { kilometer } \\ \text { kW } & \text { kilowatt } \\ \text { kWh } & \text { kilowatt-hour } \\ \text { LACE } & \text { levelized avoided cost of energy } \\ \text { LCOE } & \text { levelized cost of electricity } \\ \text { m } & \text { meter } \\ \text { MW } & \text { megawatt } \\ \text { MWh } & \text { megawatt-hour } \\ \text { NREL } & \text { National Renewable Energy Laboratory } \\ \text { OTSA } & \text { Oklahoma Tribal Statistical Area } \\ \text { POR } & \text { period of record } \\ \text { PV } & \text { photovoltaic } \\ \text { SDTSA } & \text { State Designated Tribal Statistical Area } \\ \text { TSA } & \text { Tribal Statistical Area } \\ \text { TW } & \text { terawatt } \\ \text { TWh } & \text { terawatt-hour } \\ \text { ton } & \text { short ton } \\ \text { tonne } & \text { metric ton }\end{array}$




\section{Executive Summary}

Renewable energy technologies provide opportunities for diversification, energy independence, environmental sustainability, and new revenue streams for Native American tribes, Alaska Native villages, and Alaska Native Corporations. Many of these lands are in areas that have abundant renewable energy, such as wind, solar, and biomass.

This study estimates the technical and economic potential for renewable energy development on tribal lands. Renewable energy technical potential "represents the achievable energy generation of a particular technology given system performance, topographic limitations, environmental, and land-use constraints” (Lopez et al. 2012). The primary benefit of assessing technical potential is that it establishes an upper boundary estimate of development potential and is not meant to imply market potential. Renewable energy economic potential represents the economically viable renewable generation that is available in an area. Economic potential is "the subset of available resource technical potential where the cost required to generate the electricity (which determines the minimum revenue requirements for development of the resource) is below the revenue available in terms of displaced energy and displaced capacity” (Brown et al. 2016).

This study was developed to support American Indian tribes and Alaska Natives in decisionmaking as they evaluate technologies, potential scales of development, and economic viability. The resources analyzed here include wind, solar photovoltaics (PV) and concentrating solar power (CSP), woody biomass, biogas, geothermal, and hydropower. This study provides updated information to a previous renewable energy technical potential analysis on tribal lands, Geospatial Analysis of Renewable Energy Technical Potential on Tribal Lands by Elizabeth Doris, Anthony Lopez, and Daniel Beckley. It includes current information, refined data, additional locations (for distributed generation in Alaska), and an expanded scope that includes an economic evaluation of the renewable energy potential.

Table ES-1 and Table ES-2 illustrate the results of the utility-scale technical potential on tribal lands within the noted boundaries plus an extended area of 10 miles, respectively; economic potential is presented separately. The utility-scale technical potential results are presented in terms of capacity (maximum power output measured in kilowatts [kW], megawatts [MW], etc.) and generation (the total amount of electricity generated by a power plant over a specific period of time, e.g., kilowatt-hours [kWh], megawatt-hours [MWh], etc.). The analysis shows that the utility-scale technical potential on tribal lands is approximately $6.5 \%$ of the total national technical potential. (The tribal lands compose approximately 5.8\% of the land area in the contiguous United States. ${ }^{1}$ ) The technical potential doubles when we consider tribal lands plus an extended area of 10 miles, which encompasses approximately $16.3 \%$ of the contiguous U.S. land area. ${ }^{2}$ These estimates are for tribal lands in the contiguous 48 states. Alaska Native villages are included only in the distributed generation results.

\footnotetext{
${ }^{1}$ This analysis includes some of the state reservation and statistical areas as part of the tribal boundaries geospatial data set provided by the US Census Bureau. These locations were not included in the previous tribal technical potential analysis (Doris, Lopez, and Beckley 2013); thus, the land estimate in the previous report was lower. 2 The expanded area of tribal lands plus the adjacent 10 miles is for illustrative purposes to better understand the implications of land purchases.
} 
Table ES-1. Utility-Scale Technical Potential on Tribal Lands in the Contiguous 48 States

\begin{tabular}{|c|c|c|c|c|c|c|}
\hline Technology & $\begin{array}{l}\text { Tribal } \\
\text { Capacity } \\
\text { Potential } \\
\text { (GW) }\end{array}$ & $\begin{array}{l}\text { National } \\
\text { Capacity } \\
\text { Potential } \\
(\mathrm{GW})\end{array}$ & $\begin{array}{l}\text { National } \\
\text { Capacity } \\
\text { (\%) }\end{array}$ & $\begin{array}{l}\text { Tribal } \\
\text { Generation } \\
\text { Potential } \\
\text { (TWh) }\end{array}$ & $\begin{array}{l}\text { National } \\
\text { Generation } \\
\text { Potential } \\
\text { (TWh) }\end{array}$ & $\begin{array}{l}\text { National } \\
\text { Generation } \\
\text { (\%) }\end{array}$ \\
\hline $\begin{array}{l}\text { Utility-scale } \\
\text { PV }\end{array}$ & 6,035 & 118,918 & $5 \%$ & 10,689 & 197,087 & $5.4 \%$ \\
\hline CSP & 2,114 & 26,318 & $8 \%$ & 7,701 & 92,994 & $8.3 \%$ \\
\hline Wind & 891 & 10,119 & $8.8 \%$ & 2,394 & 30,781 & $7.8 \%$ \\
\hline $\begin{array}{l}\text { Geothermal } \\
\text { (hydrothermal) }\end{array}$ & 0.033 & 5.7 & $0.6 \%$ & 0.228 & 39 & $0.6 \%$ \\
\hline $\begin{array}{l}\text { Biomass } \\
\text { (wood) }\end{array}$ & 0.542 & 34 & $1.6 \%$ & 2 & 156 & $1.6 \%$ \\
\hline Hydropower & 21 & 62 & $34.4 \%$ & 124 & 342 & $36.4 \%$ \\
\hline Total $^{\mathrm{a}}$ & 9,063 & 155,457 & $5.8 \%$ & 20,912 & 321,401 & $6.5 \%$ \\
\hline
\end{tabular}

Table ES-2. Utility-Scale Extended (Tribal Land Base Plus Adjacent 10 Miles) Technical Potential on Tribal Lands in the Contiguous 48 States

\begin{tabular}{lllllll}
\hline & $\begin{array}{l}\text { Expanded } \\
\text { Tribal } \\
\text { Area } \\
\text { Capacity } \\
\text { Potential } \\
\text { (GW) }\end{array}$ & $\begin{array}{l}\text { National } \\
\text { Capacity } \\
\text { Potential } \\
\text { (GW) }\end{array}$ & $\begin{array}{l}\text { National } \\
\text { Capacity } \\
\text { (\%) }\end{array}$ & $\begin{array}{l}\text { Expanded } \\
\text { Tribal Area } \\
\text { Generation } \\
\text { Potential } \\
\text { (TWh) }\end{array}$ & $\begin{array}{l}\text { National } \\
\text { Generation } \\
\text { Potential } \\
\text { (TWh) }\end{array}$ & $\begin{array}{l}\text { National } \\
\text { Generation } \\
\text { (\%) }\end{array}$ \\
\hline $\begin{array}{l}\text { Utility-scale } \\
\text { PV }\end{array}$ & 13,281 & 118,918 & $11.2 \%$ & 22,736 & 197,087 & $11.5 \%$ \\
CSP & 4,012 & 26,318 & $15 \%$ & 14,703 & 92,994 & $15.8 \%$ \\
Wind & 1,816 & 10,119 & $18 \%$ & 4,940 & 30,781 & $16 \%$ \\
$\begin{array}{l}\text { Geothermal } \\
\text { (hydrothermal) }\end{array}$ & 0.508 & 5.7 & $9 \%$ & 3.5 & 39 & $9 \%$ \\
$\begin{array}{l}\text { Biomass } \\
\text { (wood) }\end{array}$ & 3.7 & 34 & $10.7 \%$ & 16.8 & 156 & $10.7 \%$ \\
$\begin{array}{l}\text { Hydropower } \\
\text { Total }\end{array}$ & 39 & 62 & $63 \%$ & 225 & 342 & $65.8 \%$ \\
\hline Each & 19,153 & 155,457 & $12.3 \%$ & 42,625 & 321,401 & $13.3 \%$
\end{tabular}

${ }^{a}$ Each technology is evaluated separately; the same land area might be available for many technologies.

This report also provides an economic assessment of the utility-scale renewable energy technologies by comparing the levelized cost of energy (LCOE) to the regional wholesale market price of electricity based on 2017 price estimates. Inputs to the model include renewable energy cost and generation attributes, regional market electricity prices, and energy-support policies, among other factors. The results of this assessment indicate a sizeable but variable potential for 
land-based wind and utility-scale PV. Under this analysis, the economic potential for tribal landbased wind exceeds $1 \mathrm{GW}$, which could produce more than $3 \mathrm{TWh}$ annually. For utility-scale $\mathrm{PV}$, it is more than $61 \mathrm{GW}$, which could produce nearly $116 \mathrm{TWh}$ of electricity annually. Assuming an average installed price of $\$ 1,219 / \mathrm{kW}$ and $\$ 1,573 / \mathrm{kW}$ for solar and wind respectively, this economic potential represents over $\$ 75$ billion in project investment. The economic potential is highly sensitive to the input assumptions used; thus, the results of this analysis should be considered case-specific and illustrative only.

Technical potential estimates for distributed generation are provided for biogas only. For the remaining technologies, we provide a discussion on siting considerations due to the nature of these technologies and data availability. Biogas potential is defined by the resource availability at existing facilities, but technologies such as wind and PV can be placed almost anywhere within the tribal area based on need. We have site-specific information for biogas, but for the other technologies this information is unknown. Regarding economic potential (giving the varying performance and LCOE that systems could have), we provide estimates of the lowest LCOE that could occur in tribal areas as a guidepost for further investigation. Distributed wind and PV potential exists for every tribal area; however, in low-resource areas the resulting LCOE is high and might not be competitive with grid electricity prices. Many tribal lands have good biogas potential from the sources examined here (animal manure, wastewater sludge, and landfill material); it is likely that many locations might have good biogas potential from food waste given the number of casinos on tribal lands, especially casinos that have large food services onsite. On a site-specific basis, distributed hydropower systems are feasible on tribal lands.

Future research may include procuring higher resolution data for solar, detailed data for hydropower, and complete biomass data for Alaska. A biogas potential analysis for food waste at casinos would provide additional understanding of this technology development potential on tribal lands and support tribes' decisions regarding alternative uses of these waste materials. Future work in the economic potential assessment may include incorporating both in-region and out-of-region transmission costs; environmental benefits; policy drivers, such as renewable portfolio standards; and any sensitivities to tax-oriented policies. It is also important to understand how economic competitiveness can change when considering future modifications to renewable energy costs and projections for the broader market, prices of energy, and other related factors. This constantly changing cost profile is particularly important in determining the relative value of renewable energy compared to other replacement sources of energy. 


\section{Table of Contents}

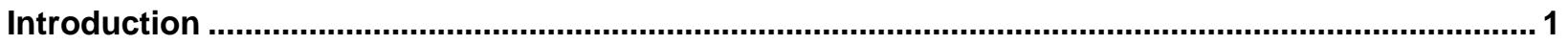

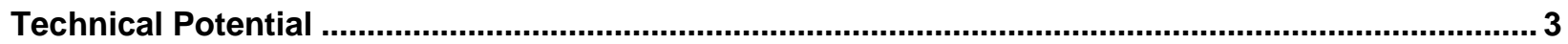

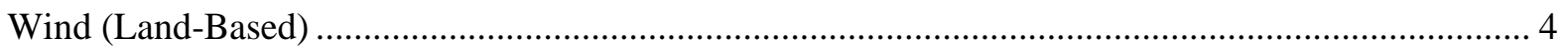

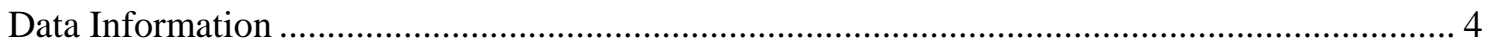

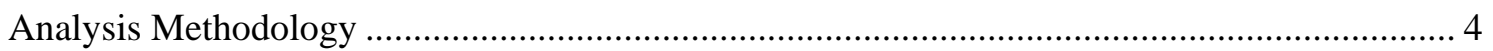

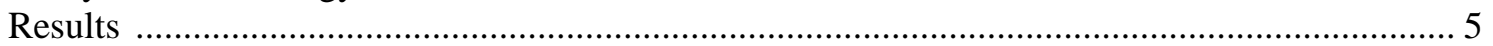

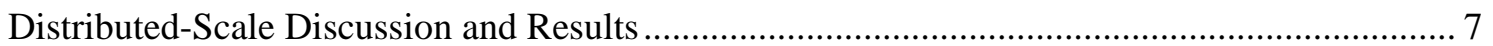

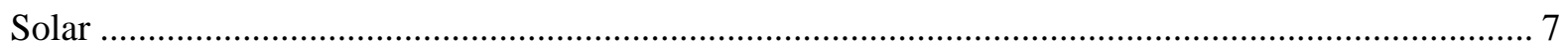

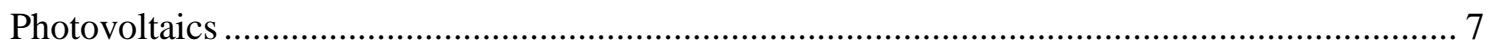

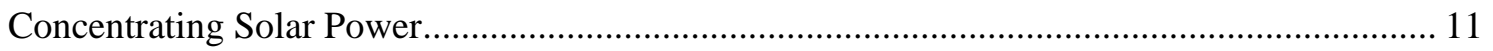

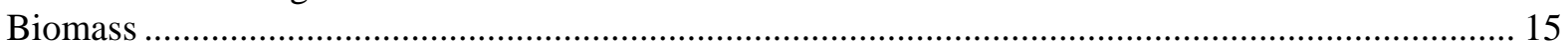

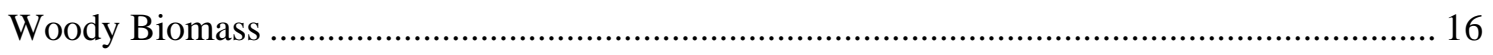

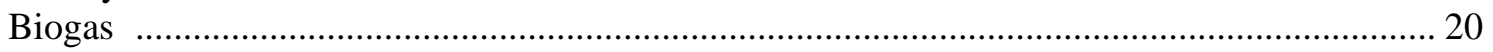

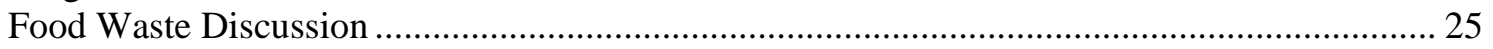

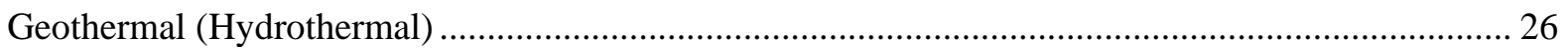

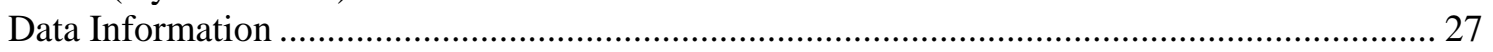

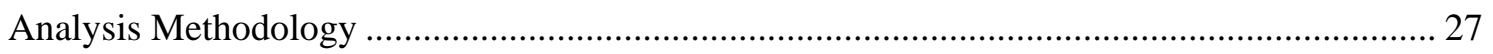

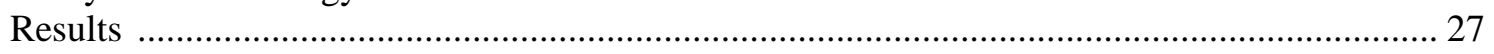

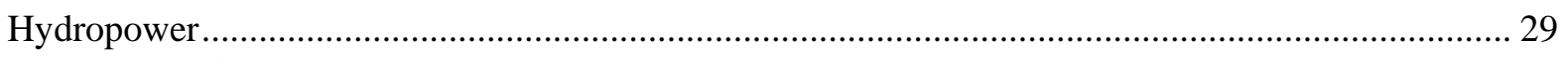

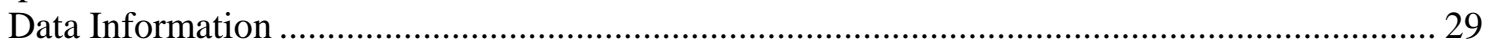

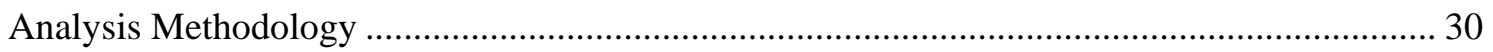

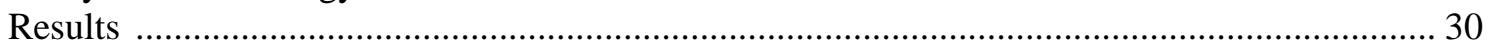

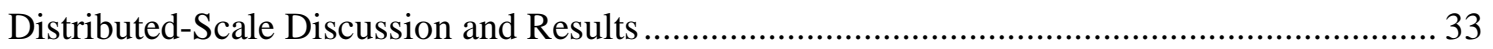

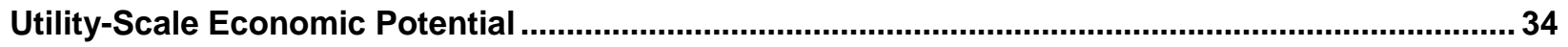

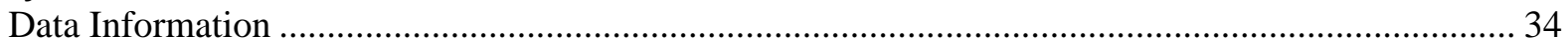

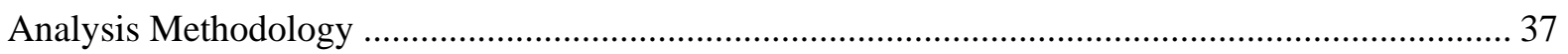

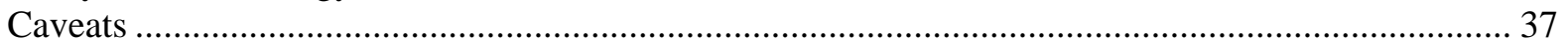

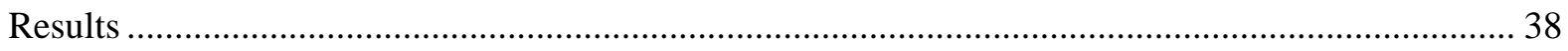

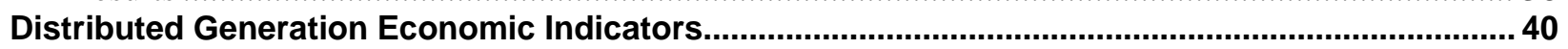

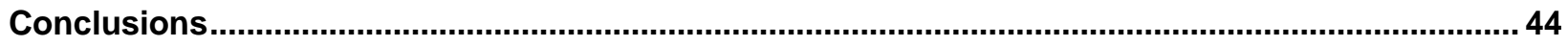

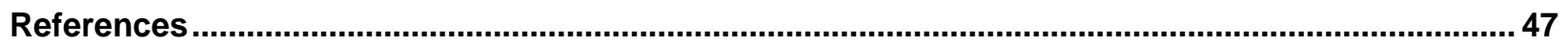

Appendix A: Technology-Specific Exclusions and Constraints ................................................... 51

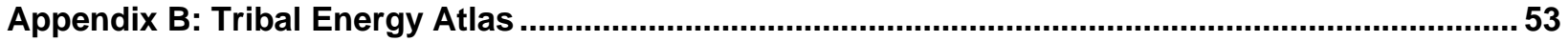




\section{List of Figures}

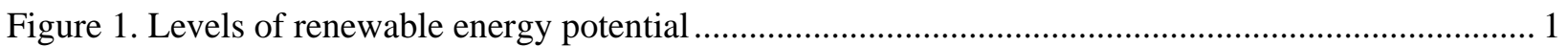

Figure 2. Wind generation potential by reservation......................................................................... 6

Figure 3. Wind generation potential by reservation (including extended areas of 10 miles adjacent to the

tribal land boundaries)

Figure 4. Photovoltaic generation potential by reservation .......................................................... 9

Figure 5. Photovoltaic generation potential by reservation (including extended areas of 10 miles adjacent

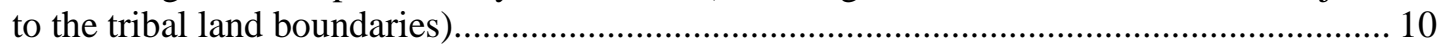

Figure 6. Concentrating solar power generation potential by reservation

Figure 7. Concentrating solar power generation potential by reservation (including extended areas of 10

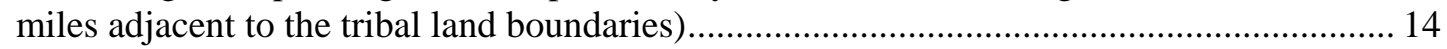

Figure 8. Biopower generation potential by reservation.

Figure 9. Biopower generation potential by reservation (including extended areas of 10 miles adjacent to the tribal land boundaries).................................................................................................... 19

Figure 10. Biogas power generation potential by reservation.................................................................. 23

Figure 11. Biogas power generation potential by reservation (including extended areas of 10 miles

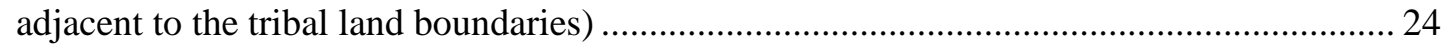

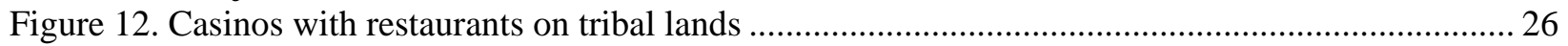

Figure 13. Geothermal generation potential by reservation .................................................................. 28

Figure 14. Geothermal generation potential by reservation (including extended areas of 10 miles adjacent

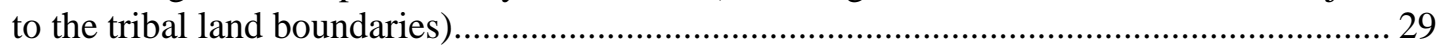

Figure 15. Hydropower generation potential by reservation .............................................................. 31

Figure 16. Hydropower generation potential by reservation (including extended areas of 10 miles adjacent

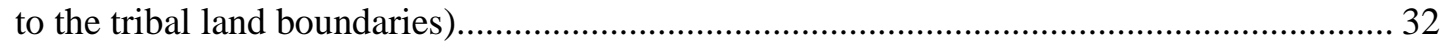

Figure 17. Market price estimate with projected price changes from 2014-2034 and levelized to an

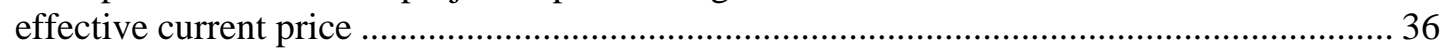

Figure 18. Potential distributed wind levelized cost of energy in tribal areas .......................................... 41

Figure 19. Potential distributed photovoltaic levelized cost of energy in tribal areas .............................. 42

Figure 20. Potential biogas levelized cost of energy in tribal areas..................................................... 42

Figure 21. Potential small-scale hydropower levelized cost of energy in tribal areas ............................. 43

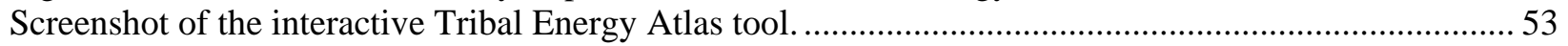




\section{List of Tables}

Table ES-1. Utility-Scale Technical Potential on Tribal Lands in the Contiguous 48 States .....................vi

Table ES-2. Utility-Scale Extended (Tribal Land Base Plus Adjacent 10 Miles) Technical Potential on

Tribal Lands in the Contiguous 48 States ......................................................................... vi

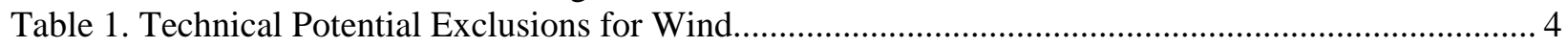

Table 2. Wind Generation and Capacity Potential on Tribal Lands ........................................................... 5

Table 3. Fifteen Tribal Lands with the Highest Technical Potential for Wind Electricity Generation.......... 7

Table 4. Technical Potential Exclusions for Utility-Scale Photovoltaics ................................................ 8

Table 5. Photovoltaic Generation and Capacity Potential on Tribal Lands .............................................. 9

Table 6. Fifteen Tribal Lands with the Highest Technical Potential for Photovoltaic Electricity Generation

Table 7. Technical Potential Exclusions for Utility-Scale Concentrating Solar Power

Table 8. Concentrating Solar Power Generation and Capacity Potential on Tribal Lands ......................... 13

Table 9. Fifteen Tribal Lands with the Highest Technical Potential for Concentrating Solar Power

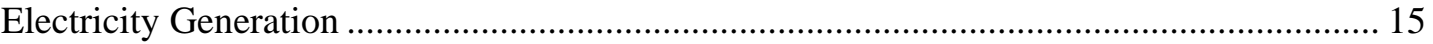

Table 10. Biomass Resource and Land Cover Pairings .......................................................................... 17

Table 11. Woody Biomass Power Generation and Capacity Potential on Tribal Lands............................. 18

Table 12. Fifteen Tribal Lands with the Highest Technical Potential for Biopower Generation from

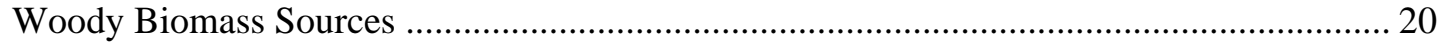

Table 13. Biogas Generation and Capacity Potential on Tribal Lands ..................................................... 23

Table 14. Fifteen Tribal Lands with the Highest Technical Potential for Biogas Power Generation.......... 25

Table 15. Geothermal Generation and Capacity Potential on Tribal Lands ............................................ 27

Table 16. Tribal Lands with the Highest Technical Potential for Geothermal Electricity Generation ........ 29

Table 17. Hydropower Generation and Capacity Potential on Tribal Lands ............................................ 30

Table 18. Fifteen Tribal Lands with the Highest Technical Potential for Hydropower Generation ............ 33

Table 19. Overview of Renewable Energy Technology Cost Assumptions ............................................... 35

Table 20. Estimated Tribal Economic Potential for the 48 Contiguous States at Utility Scale Based on Site

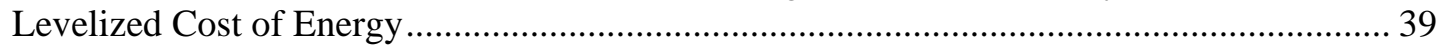

Table 21. Overview of Renewable Energy Technology Cost Assumptions (2015 U.S. Dollars)............... 40

Table 22. Distributed Generation Range of Levelized Cost of Energy ${ }^{\mathrm{a}}$................................................... 41

Table 23. Utility-Scale Technical Potential on Tribal Lands in the Contiguous 48 States by Capacity and

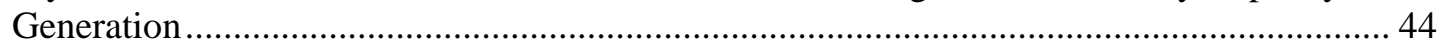

Table 24. Utility-Scale Extended (Tribal Land Base Plus Adjacent 10 Miles) Technical Potential on Tribal Lands in the Contiguous 48 States by Capacity and Generation................................. 45

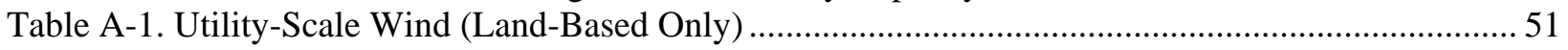

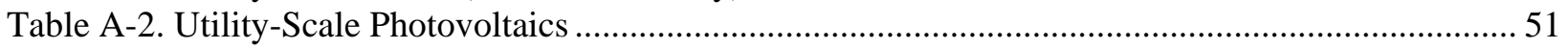

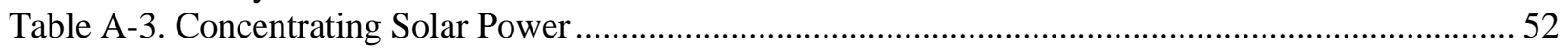




\section{Introduction}

Renewable energy technologies could provide an opportunity for diversification, energy independence, environmental sustainability, and new revenue streams for Native American tribes, Alaska Native villages, and Alaska Native Corporations. Many of these lands are in areas that have abundant renewable energy resources, such as wind, solar, and biomass.

The purpose of this study is to estimate the technical and economic potential for renewable energy development on tribal lands. It aims to support tribes in decision-making as they evaluate technologies, the potential scale of development, and economic viability. The resources analyzed here include wind, solar photovoltaics (PV) and concentrating solar power (CSP), woody biomass, biogas, geothermal, and hydropower. This study provides updated information to a previous renewable energy technical potential analysis on tribal lands (Doris, Lopez, and Beckley 2013). It includes current information, refined data, additional locations (in Alaska), and an expanded scope to include an economic evaluation of the renewable energy potential.

Note that there are several different levels of renewable energy potential, as illustrated in Figure 1, including resource, technical, economic, and market potential. This study focuses on technical and economic potential estimates. Renewable energy technical potential "represents the achievable energy generation of a particular technology given system performance, topographic limitations, environmental, and land-use constraints” (Lopez et al. 2012). The primary benefit of assessing technical potential is that it establishes an upper boundary estimate of development potential.

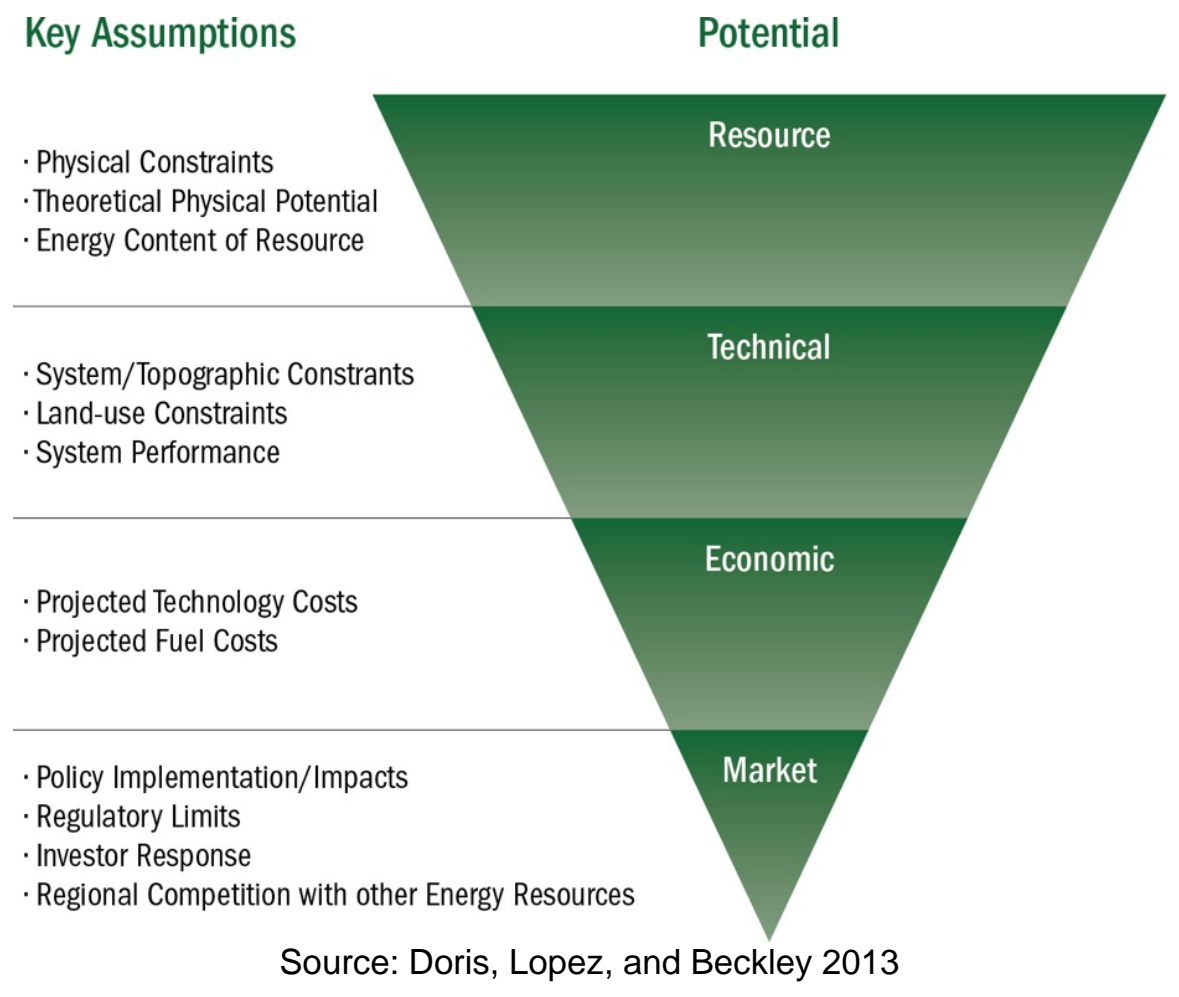

Figure 1. Levels of renewable energy potential 
Renewable energy economic potential represents the economically viable renewable generation that is available in an area. Economic potential is "the subset of available resource technical potential where the cost required to generate the electricity (which determines the minimum revenue requirements for development of the resource) is below the revenue available in terms of displaced energy and displaced capacity” (Brown et al. 2016). 


\section{Technical Potential}

Technical potential is an evaluation of the resource potential that theoretically could be developed by considering the siting requirements for a given technology and incorporating the technology-specific performance characteristics. This analysis uses a previously published methodology (Lopez et. al. 2012; Doris, Lopez, and Beckley et al. 2013; Saur and Milbrandt 2014) that has been updated to reflect more recent modeled resource data sets and an improved representation of the tribal land boundaries. It also expands the lands under consideration to include areas near reservations that might be candidates for future acquisitions, for illustrative purposes. The areas considered are within 10 miles of the tribal boundaries. Most of the results discussed in this report focus on utility-scale development potential, but a summary of distributed generation technology considerations is also included. Alaska Native villages are included only in the distributed generation results and discussion.

The methodology for determining the technical potential on tribal lands is to:

1. Identify the resource areas associated with the tribal land boundaries and within 10 miles of those lands.

2. Apply exclusions representing the technical feasibility limits for siting or implementing that technology as appropriate (e.g., slopes, incompatible land use areas, etc.).

3. Estimate the available land area remaining that may be suitable for each technology's development.

4. Apply technology-specific performance characteristics to estimate the potential installed capacity and net generation.

Note that the technical potential estimate should be considered a maximum potential estimate. Many considerations must be factored into a decision to develop a site (e.g., cost of development, demand, alternative uses for the site). This analysis does not exclude culturally sensitive areas or areas already in use that would not be appropriate for development that are not part of national, publicly available data sets.

The boundaries for the Native American tribes, Alaska Native villages, and Alaska Native Corporations were obtained from the U.S. Census Bureau (2016). This is the most recent and comprehensive database of tribal lands, and it includes federally recognized tribes, state reservation lands, off-reservation trust lands, and tribal statistical areas (TSAs, e.g., Oklahoma [OTSA] and State Designated [SDTSA] in tables of results). ${ }^{3}$ Results are reported separately for the U.S. Census boundaries and the areas including 10 miles surrounding the tribal land. Where multiple tribal areas exist within 10 miles, the extended area was allocated to only the nearest tribal boundary area.

\footnotetext{
${ }^{3}$ In January 2018, six Virginia tribes received federal recognition: the Chickahominy, Eastern Chickahominy, Upper Mattaponi, Rappahannock, Monacan, and Nansemond. Two of the tribes, Chickahominy and Eastern Chickahominy, are included in this analysis, as we have information on their boundaries. At the time of publication, we do not have geospatial data for the remaining four tribes; thus, they are not included in this study.
} 
The detailed methodologies for determining the available resource, as well as the technology assumptions to convert the resource area to installed capacity and net generation, are described for each resource type as follows.

\section{Wind (Land-Based)}

Wind power harvests energy by converting the kinetic energy of wind into electricity through spinning wind turbine blades as the wind moves through an area. Wind is a variable generator, and modeled hourly wind resource data are used in conjunction with specific wind turbine power curves to estimate potential energy production. Utility-scale applications typically use wind speeds at wind turbine hub heights of $80 \mathrm{~m}$ above the surface, as demonstrated in the 2016 Wind Technologies Market Report (Wiser and Bolinger 2017).

\section{Data Information}

This analysis uses modeled wind resource data from the Wind Integration National Dataset Toolkit (Draxl et al. 2015). This data set was developed as a high spatial (2 km x $2 \mathrm{~km})$ and high temporal (5-min) resolution data set for wind energy applications. It differs from wind resource data used previously because the model's period of record (POR) (2007-2013) is long enough to capture some interannual variability but not long enough to be representative of the long-term average resource, and because the coarser spatial resolution (2 km instead of $200 \mathrm{~m}-1 \mathrm{~km}$ ) might miss some wind-force features in complex terrain. Since the data are accessible free of charge to the public, they can be used directly by tribal analysts for more detailed investigation.

\section{Analysis Methodology}

An annual average resource data set was created by summarizing the full POR of the data set for a hub height of $80 \mathrm{~m}$ above ground and hourly wind speed values for the full POR processed against a wind turbine power curve that was selected based on the annual average wind speed.

\section{Technical Potential Exclusions}

Wind power facilities comprise one or more individually placed wind turbines, often organized in one or more rows oriented toward the prevailing wind direction. The individual placement of wind turbines allows some flexibility in siting. This analysis did not use a minimum wind resource threshold, but used the technical exclusions summarized in Table 1, which are listed in detail in Appendix A. The exclusions are modified from those used in Lopez et al. (2012).

Table 1. Technical Potential Exclusions for Wind

Slopes $>20 \%$

Incompatible land use areas (wetland, water, urban areas, non-ridgecrest forest)

Protected areas (parks, wilderness, wildlife refuges, etc.) 


\section{Technology Characterization}

A variety of wind turbine models are available that can be customized to optimize output from specific wind climates. Three primary classes of turbines represent broad wind climates based on the modeled annual average wind speed:

- International Electrotechnical Commission Class 1: annual average wind speed $>9 \mathrm{~m} / \mathrm{s}$

- International Electrotechnical Commission Class II: annual average wind speed between $8 \mathrm{~m} / \mathrm{s}$ and $9 \mathrm{~m} / \mathrm{s}$

- International Electrotechnical Commission Class III: annual average wind speed $\leq 8 \mathrm{~m} / \mathrm{s}$. The installation density for a wind power facility is assumed to be $3 \mathrm{MW} / \mathrm{km}^{2}$. This reflects a very open turbine spacing in a wind power facility and can be taken as a conservative estimate of potential capacity. The hourly wind profiles for each modeled site were processed against the selected wind turbine power curve using the National Renewable Energy Laboratory's (NREL's) System Advisor Model, a performance and financial model designed to facilitate decisionmaking in the renewable energy industry.

\section{Results}

Table 2 illustrates the results of this analysis and summarizes the wind generation and capacity potential on tribal lands. The base resource potential is shown for comparative purposes. The base potential represents the wind resource potential if all the land within the tribal boundary were used for wind development. The table shows that approximately $40 \%$ of tribal land areas $\left(200,762 \mathrm{~km}^{2}\right.$ out of $\left.497,942 \mathrm{~km}^{2}\right)$ are excluded by the technical potential criteria. In the expanded tribal area (within 10 miles of a reservation), approximately $57 \%$ of land areas $\left(806,329 \mathrm{~km}^{2}\right.$ out of $\left.1,411,749 \mathrm{~km}^{2}\right)$ are excluded.

Table 2. Wind Generation and Capacity Potential on Tribal Lands

\begin{tabular}{llll}
\hline Scenario & $\begin{array}{l}\text { Generation } \\
\text { (MWh) }\end{array}$ & $\begin{array}{l}\text { Capacity } \\
\text { (MW) }\end{array}$ & $\begin{array}{l}\text { Area } \\
\mathbf{( k m}^{\mathbf{2}}\end{array}$ \\
\hline Tribal lands (base potential) & $3,991,272,885$ & $1,493,825$ & 497,942 \\
Tribal lands (technical exclusions) & $2,394,384,664$ & 891,540 & 297,180 \\
Expanded tribal lands (base potential) & $11,202,177,751$ & $4,235,247$ & $1,411,749$ \\
Expanded tribal lands (technical potential) & $4,940,289,138$ & $1,816,261$ & 605,420 \\
\hline
\end{tabular}

Figure 2 and Figure 3 illustrate the wind generation potential by reservation and within the extended areas, and Table 3 shows the 15 tribal lands with the highest technical potential for wind electricity generation. 


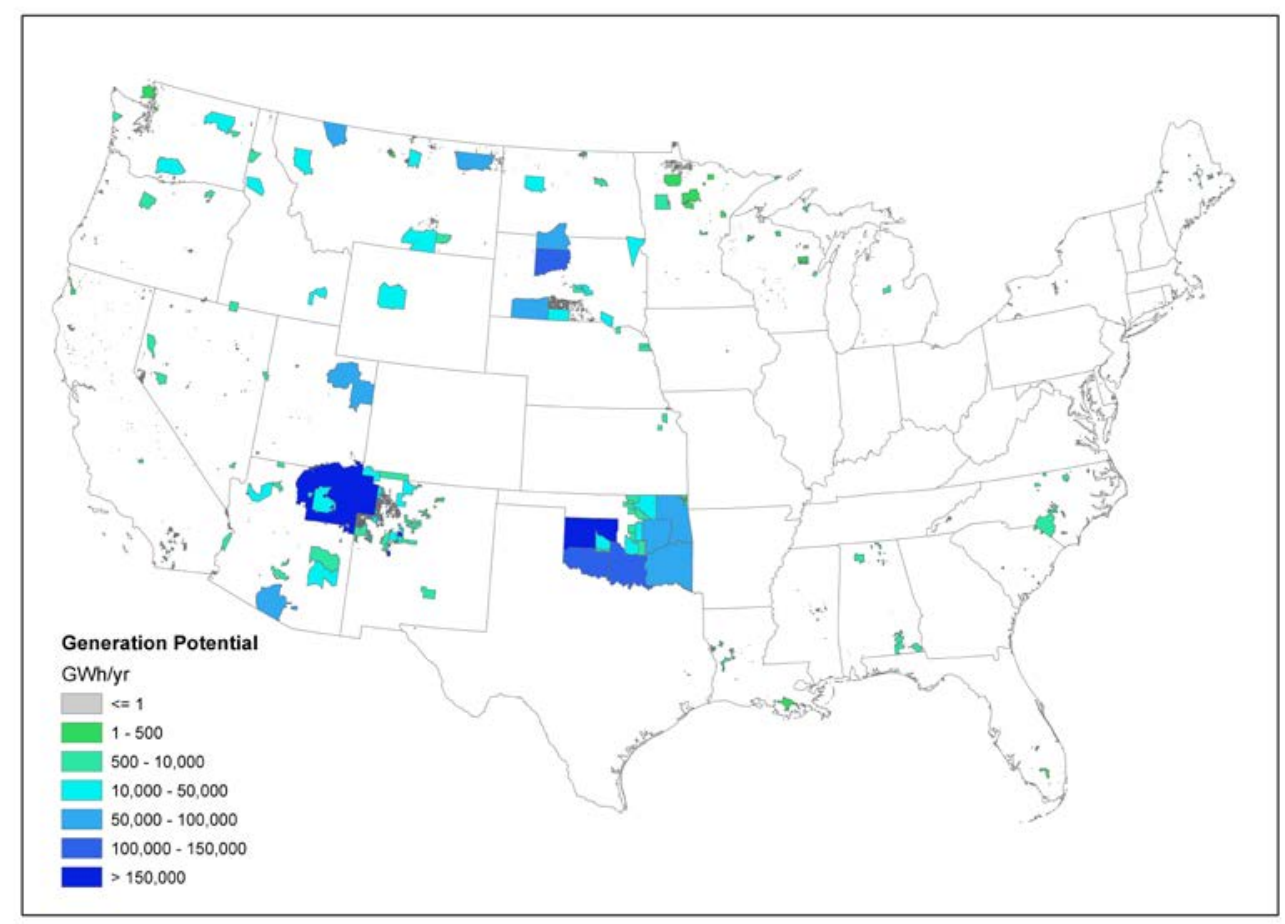

Figure 2. Wind generation potential by reservation

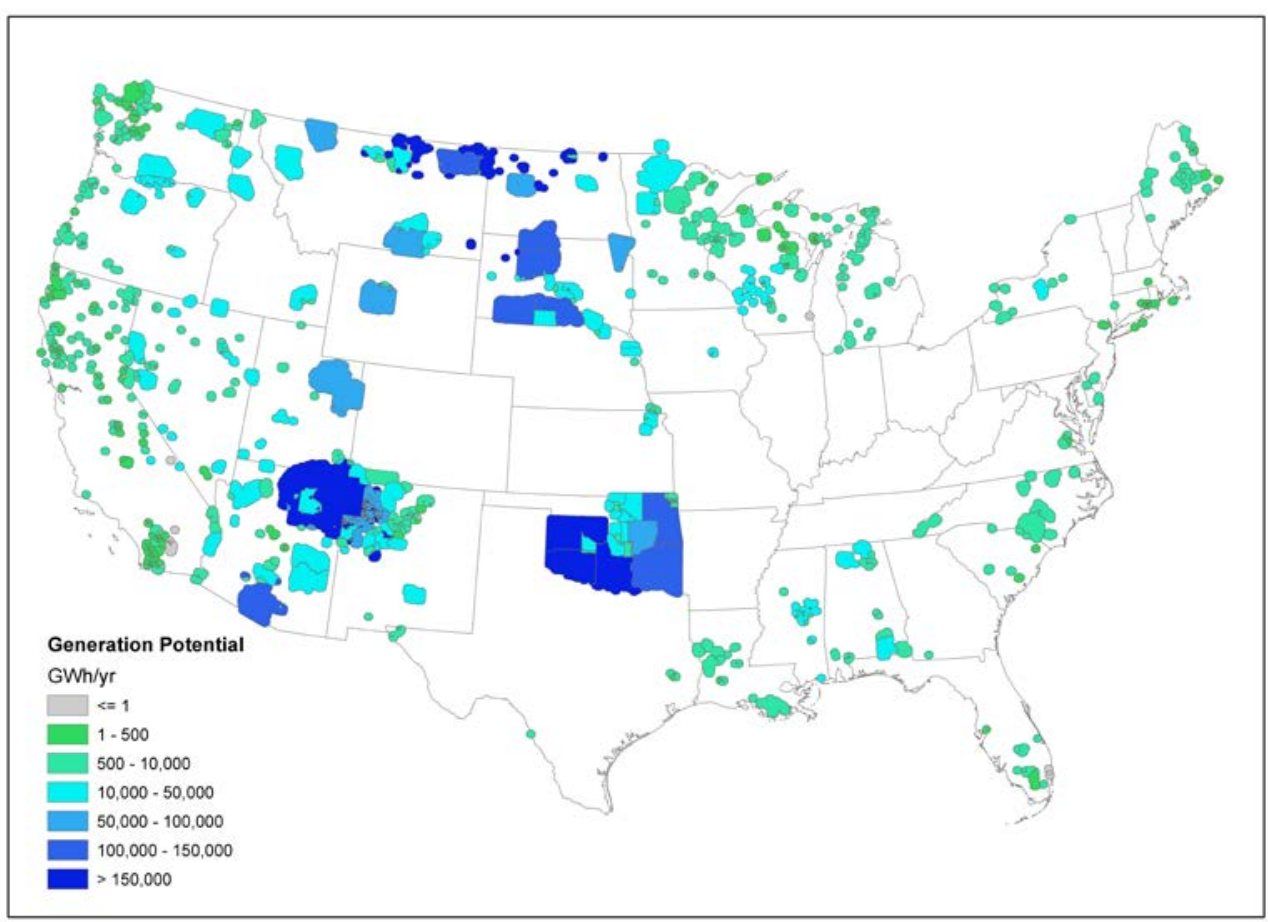

Figure 3. Wind generation potential by reservation (including extended areas of 10 miles adjacent to the tribal land boundaries) 
Table 3. Fifteen Tribal Lands with the Highest Technical Potential for Wind Electricity Generation

\begin{tabular}{|c|c|c|c|c|}
\hline Tribal Area & State & $\begin{array}{l}\text { Net } \\
\text { Generation } \\
\text { (MWh) }\end{array}$ & $\begin{array}{l}\text { Installed } \\
\text { Capacity } \\
\text { (MW) }\end{array}$ & $\begin{array}{l}\text { Available } \\
\text { Land } \\
\text { Area } \\
\left(\mathrm{km}^{2}\right)\end{array}$ \\
\hline Navajo & Arizona & $329,108,277$ & 162,427 & 54,142 \\
\hline $\begin{array}{l}\text { Cheyenne-Arapaho Oklahoma } \\
\text { Tribal Statistical Area (OTSA) }\end{array}$ & Oklahoma & $192,695,076$ & 53,715 & 17,905 \\
\hline $\begin{array}{l}\text { Kiowa-Comanche-Apache-Fort } \\
\text { Sill Apache OTSA }\end{array}$ & Oklahoma & $141,282,876$ & 42,340 & 14,113 \\
\hline Chickasaw OTSA & Oklahoma & $129,052,128$ & 40,094 & 13,365 \\
\hline Cheyenne River & South Dakota & $102,704,890$ & 29,249 & 9,750 \\
\hline Cherokee OTSA & Oklahoma & $92,356,954$ & 29,132 & 9,711 \\
\hline Choctaw OTSA & Oklahoma & $90,662,537$ & 35,085 & 11,695 \\
\hline Pine Ridge & South Dakota & $87,626,718$ & 24,273 & 8,091 \\
\hline Standing Rock & North Dakota & $84,382,346$ & 23,324 & 7,775 \\
\hline Fort Peck & Montana & $77,546,643$ & 21,523 & 7,174 \\
\hline Tohono O'odham & Arizona & $77,026,972$ & 43,457 & 14,486 \\
\hline Creek OTSA & Oklahoma & $59,235,489$ & 18,194 & 6,065 \\
\hline Blackfeet & Montana & $52,991,185$ & 14,415 & 4,805 \\
\hline Uintah and Ouray & Utah & $52,474,520$ & 30,159 & 10,053 \\
\hline Crow & Montana & $46,250,649$ & 17,472 & 5,824 \\
\hline
\end{tabular}

\section{Distributed-Scale Discussion}

Distributed-scale wind development typically consists of a single turbine or a few turbines, and the turbines are smaller in size than those used for utility-scale development. Hub heights of 30 $\mathrm{m}-50 \mathrm{~m}$ are common, but they are also reported to range between $6 \mathrm{~m}$ and $100 \mathrm{~m}$ (Orrell et. al. 2017). In general, the wind resource is reduced as the hub height is lowered. The wind resource at lower hub heights can be dramatically influenced by the surrounding topography and vegetation, and extra care must be taken to site the turbines appropriately. Depending on the wind climate, exposed topographic features, such as cleared ridge crests, could be more attractive for development.

Broadly, tribal lands in Alaska, the western United States, and the Great Plains contain highquality resource potential for wind, even at lower hub heights. In the eastern and southeastern United States, wind opportunities are more limited.

\section{Solar}

\section{Photovoltaics}

PV technologies directly convert the energy of the sun to electricity. Utility-scale PV links multiple individual solar panels to a solar power facility. The solar panels can be set up simply as 
fixed flat-plate systems, or they can be designed to track the movement of the sun to increase system performance.

\section{Data Information}

This analysis uses the latest update of the National Solar Radiation Database produced by NREL in 2016 (Habte, Sengupta, and Lopez 2017). This data set has a higher spatial resolution than that used in previous analyses (4 km instead of $10 \mathrm{~km}$ ). Half-hourly resolution time-series data are publicly available for the entire POR. Hourly summarized global solar horizontal irradiance for the period from 2000-2014 was used to characterize system performance.

\section{Analysis Methodology}

\section{Technical Potential Exclusions}

Solar power facilities comprise multiple solar collectors that are physically connected in a concentrated area. This analysis did not use a minimum solar resource threshold, but used the technical exclusions summarized in Table 4, which are listed in detail in Appendix A. The exclusions are modified from those in Lopez et al. (2012).

Table 4. Technical Potential Exclusions for Utility-Scale Photovoltaics

Slopes $>5 \%$

Minimum contiguous area of $1 \mathrm{~km}^{2}$

Incompatible land use areas (wetland, water, urban areas, forested areas)

Protected areas (parks, wilderness, wildlife refuges, etc.)

\section{Technology Characterization}

PV systems can be customized to individual solar site characteristics and project needs. For this analysis, a single-axis tracking system was used to represent a typical utility-scale system as described in the Annual Technology Baseline (ATB) developed by NREL (NREL 2017). Hourly solar resource data for the POR 2000-2014 for each modeled site were used with this system configuration to estimate long-term average system performance, with an assumption of $14 \%$ system losses. The installation density for this type of solar power facility is assumed to be 32 $\mathrm{MW} / \mathrm{km}^{2}$.

\section{Results}

Table 5 illustrates the results of this analysis and summarizes the PV generation and capacity potential on tribal lands. The base resource potential is shown for comparative purposes. The base potential represents the utility-scale PV resource potential if all the land within the tribal boundary were to be used for PV development. This table shows that approximately 57\% of tribal land areas are excluded by the technical potential criteria used in the analysis. In the expanded tribal area, approximately $67 \%$ of land areas are excluded. 
Table 5. Photovoltaic Generation and Capacity Potential on Tribal Lands

\begin{tabular}{llll}
\hline Scenario & $\begin{array}{l}\text { Generation } \\
\text { (MWh) }\end{array}$ & $\begin{array}{l}\text { Capacity } \\
\text { (MW) }\end{array}$ & $\begin{array}{l}\text { Area } \\
\mathbf{( k m}^{\mathbf{2}}\end{array}$ \\
\hline Tribal lands (base potential) & $24,526,365,637$ & $14,111,101$ & 361,823 \\
Tribal lands (technical exclusions) & $10,689,346,455$ & $6,035,850$ & 154,765 \\
Expanded tribal lands (base potential) & $66,712,060,544$ & $39,862,842$ & $1,022,124$ \\
Expanded tribal lands (technical potential) & $22,736,684,931$ & $13,281,491$ & 340,551 \\
\hline
\end{tabular}

Figure 4 and Figure 5 illustrate the PV generation potential by reservation and within the extended areas, and Table 6 shows the 15 tribal lands with the highest technical potential for PV electricity generation.

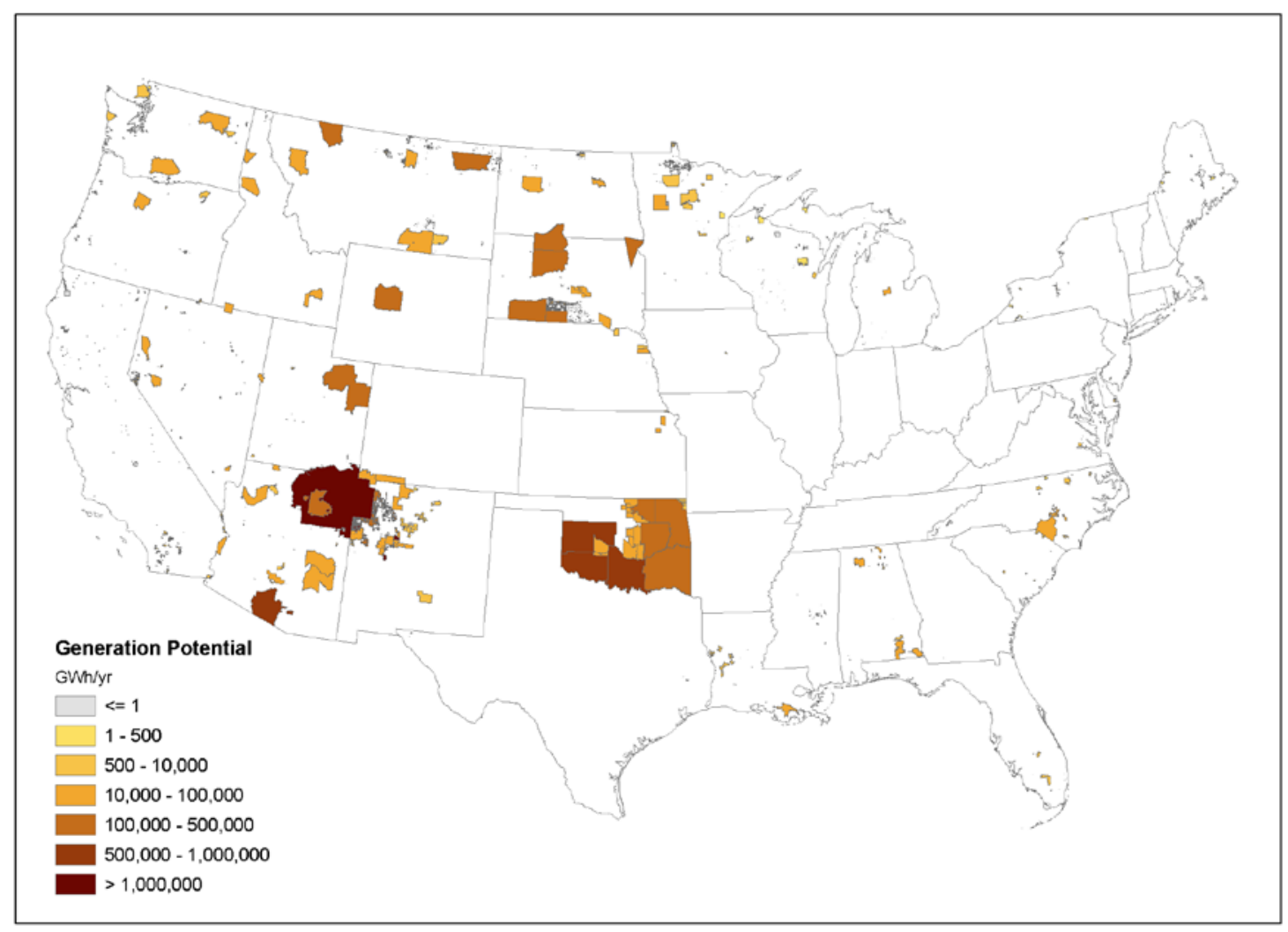

Figure 4. Photovoltaic generation potential by reservation 


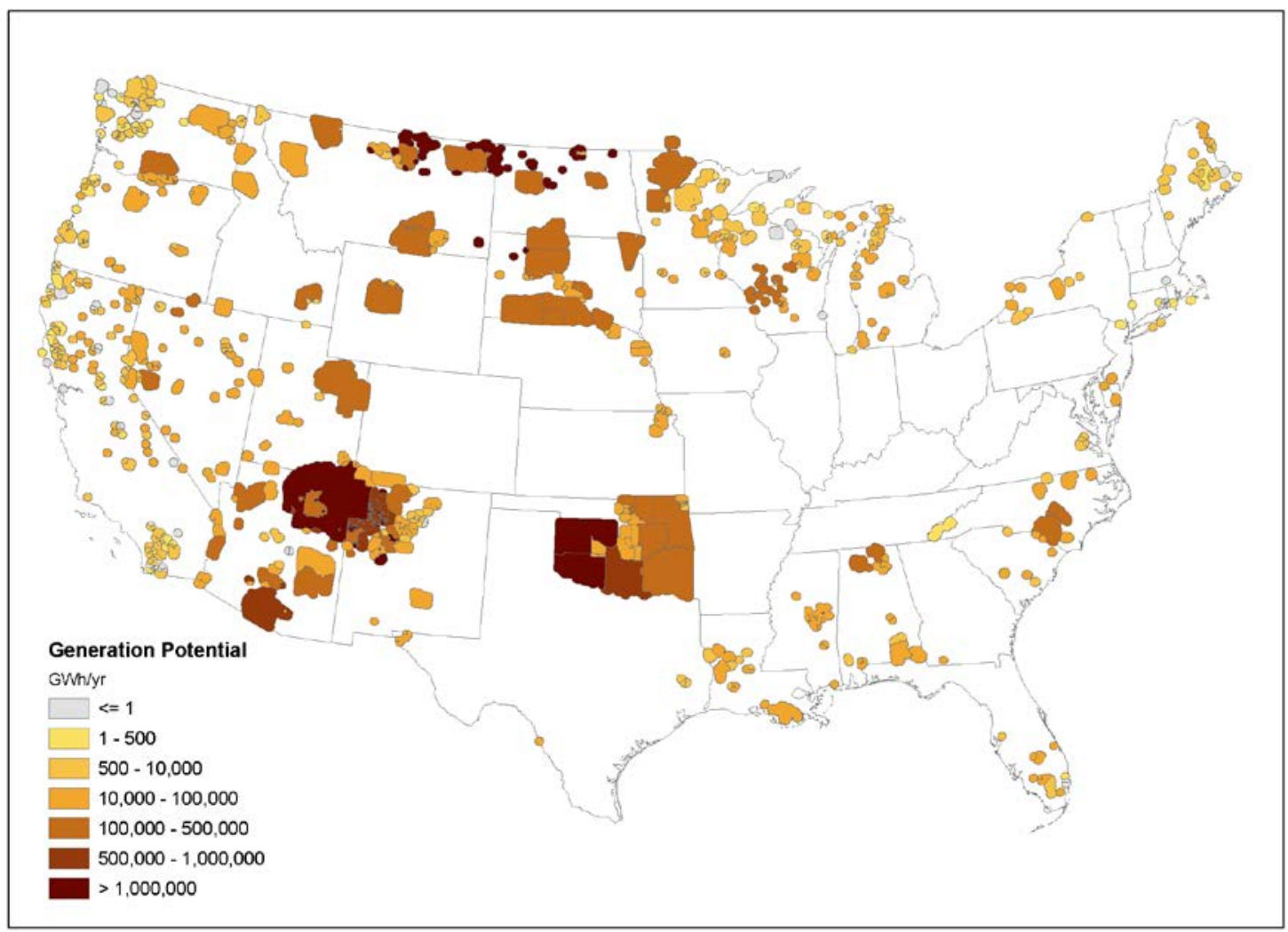

Figure 5. Photovoltaic generation potential by reservation (including extended areas of 10 miles adjacent to the tribal land boundaries) 
Table 6. Fifteen Tribal Lands with the Highest Technical Potential for Photovoltaic Electricity Generation

\begin{tabular}{|c|c|c|c|c|}
\hline Tribal Area & State & $\begin{array}{l}\text { Net } \\
\text { Generation } \\
\text { (MWh) }\end{array}$ & $\begin{array}{l}\text { Capacity } \\
\text { (MW) }\end{array}$ & $\begin{array}{l}\text { Available } \\
\text { Land Area } \\
\left(\mathrm{km}^{2}\right)\end{array}$ \\
\hline Navajo & Arizona & $1,829,621,623$ & 902,154 & 18,987 \\
\hline Cheyenne-Arapaho OTSA & Oklahoma & $908,307,892$ & 498,444 & 10,188 \\
\hline $\begin{array}{l}\text { Kiowa-Comanche-Apache-Fort } \\
\text { Sill Apache OTSA }\end{array}$ & Oklahoma & $769,386,990$ & 421,026 & 10,470 \\
\hline Chickasaw OTSA & Oklahoma & $618,421,613$ & 354,212 & 12,525 \\
\hline Tohono O'odham & Arizona & $587,704,601$ & 281,190 & 6,205 \\
\hline Cherokee OTSA & Oklahoma & $405,493,464$ & 246,585 & 5,450 \\
\hline Choctaw OTSA & Oklahoma & $387,527,056$ & 236,164 & 9,570 \\
\hline Cheyenne River & $\begin{array}{l}\text { South } \\
\text { Dakota }\end{array}$ & $327,094,263$ & 209,098 & 4,207 \\
\hline Standing Rock & $\begin{array}{l}\text { North } \\
\text { Dakota }\end{array}$ & $311,995,049$ & 203,589 & 8,069 \\
\hline Pine Ridge & $\begin{array}{l}\text { South } \\
\text { Dakota }\end{array}$ & $303,651,295$ & 185,258 & 6,282 \\
\hline Fort Peck & Montana & $293,095,619$ & 205,564 & 3,369 \\
\hline Hopi & Arizona & $267,273,652$ & 130,149 & 1,541 \\
\hline Creek OTSA & Oklahoma & $248,846,869$ & 149,093 & 3,505 \\
\hline Uintah and Ouray & Utah & $188,782,415$ & 104,363 & 1,919 \\
\hline Wind River & Wyoming & $171,578,016$ & 98,232 & 3,253 \\
\hline
\end{tabular}

\section{Distributed-Scale Discussion}

Distributed-scale PV development typically consists of smaller roof- or ground-mounted panels with a fixed tilt. Suitability for roof- and/or ground-mounted system installation might be impacted by site characteristics, such as roof orientation, pitch, age, and shading from surrounding buildings and vegetation. Battery storage systems paired with solar PV (and wind) are increasingly common to achieve baseload power at all times and to better control power use relative to peak demand charges and other energy rates. Although the increased solar resource availability makes distributed PV more productive for tribes in the southern United States, technical potential exists for every tribal area in the United States.

\section{Concentrating Solar Power}

CSP technologies use trough or tower systems that concentrate the heat energy of the sun into a small area. Collected thermal energy is then transferred to high-temperature fluids (HTF), commonly molten salt, which provides thermal energy capable of transferring water to steam, which is applied to a turbine and produces electricity. This process enables a CSP system to store 
energy in HTF for a period of time or immediately transfer the thermal energy to power, providing more flexibility in utilizing an intermittent solar resource.

\section{Data Information}

This analysis uses previously developed CSP technical potential data sets and the 2015 version of the National Solar Radiation Database. This is a direct normal irradiation data set, and it has a 10-km spatial resolution.

\section{Analysis Methodology}

\section{Technical Potential Exclusions}

CSP facilities comprise multiple solar collectors focused on a central point, either a centrally located tower or the center of a parabolic trough array. This characteristic necessitates that the collectors are placed precisely to ensure that the collectors function correctly. The collectors move to track the sun, so they use direct normal irradiance fully. A minimum solar resource threshold was used in this analysis as an annual direct normal resource of $5 \mathrm{kWh} / \mathrm{m}^{2} / \mathrm{d}$. Table 7 summarizes the technical exclusions, which are listed in detail in Appendix A. The exclusions are modified from those in Lopez et al. (2012).

Table 7. Technical Potential Exclusions for Utility-Scale Concentrating Solar Power

Slopes $>3 \%$

Minimum contiguous area of $1 \mathrm{~km}^{2}$

Incompatible land use areas (wetland, water, urban areas)

Protected areas (parks, wilderness, wildlife refuges, etc.)

\section{Technology Characterization}

The system modeled consists of a solar power tower with a solar multiple of 2.4 and $10 \mathrm{~h}$ of storage. System performance was modeled using NREL's Solar Advisor Model and the typical meteorological hourly profile data for each region. The installation density is assumed to be 19.4 $\mathrm{MW} / \mathrm{km}^{2}$.

\section{Results}

Table 8 illustrates the results of this analysis and summarizes the CSP generation and capacity potential on tribal lands. Figure 6 and Figure 7 illustrate the CSP generation potential by reservation and within the extended areas, and Table 9 shows the 15 tribal lands with the highest technical potential for CSP electricity generation. The resource threshold applied to the technical potential effectively limits the results to the western United States, with some limited viable areas in Florida. 
Table 8. Concentrating Solar Power Generation and Capacity Potential on Tribal Lands

\begin{tabular}{llll}
\hline Scenario & $\begin{array}{l}\text { Generation } \\
\text { (MWh) }\end{array}$ & $\begin{array}{l}\text { Capacity } \\
\text { (MW) }\end{array}$ & $\begin{array}{l}\text { Area } \\
\left.\mathbf{( k m}^{2}\right)\end{array}$ \\
\hline Tribal lands (technical exclusions) & $7,701,328,141$ & $2,114,570$ & 108,750 \\
Expanded tribal lands (technical potential) & $1,470,311,455$ & $4,011,578$ & 206,310
\end{tabular}

Note: This project is leveraging an existing analysis that was already filtered, thus we are unable to calculate a base generation value.

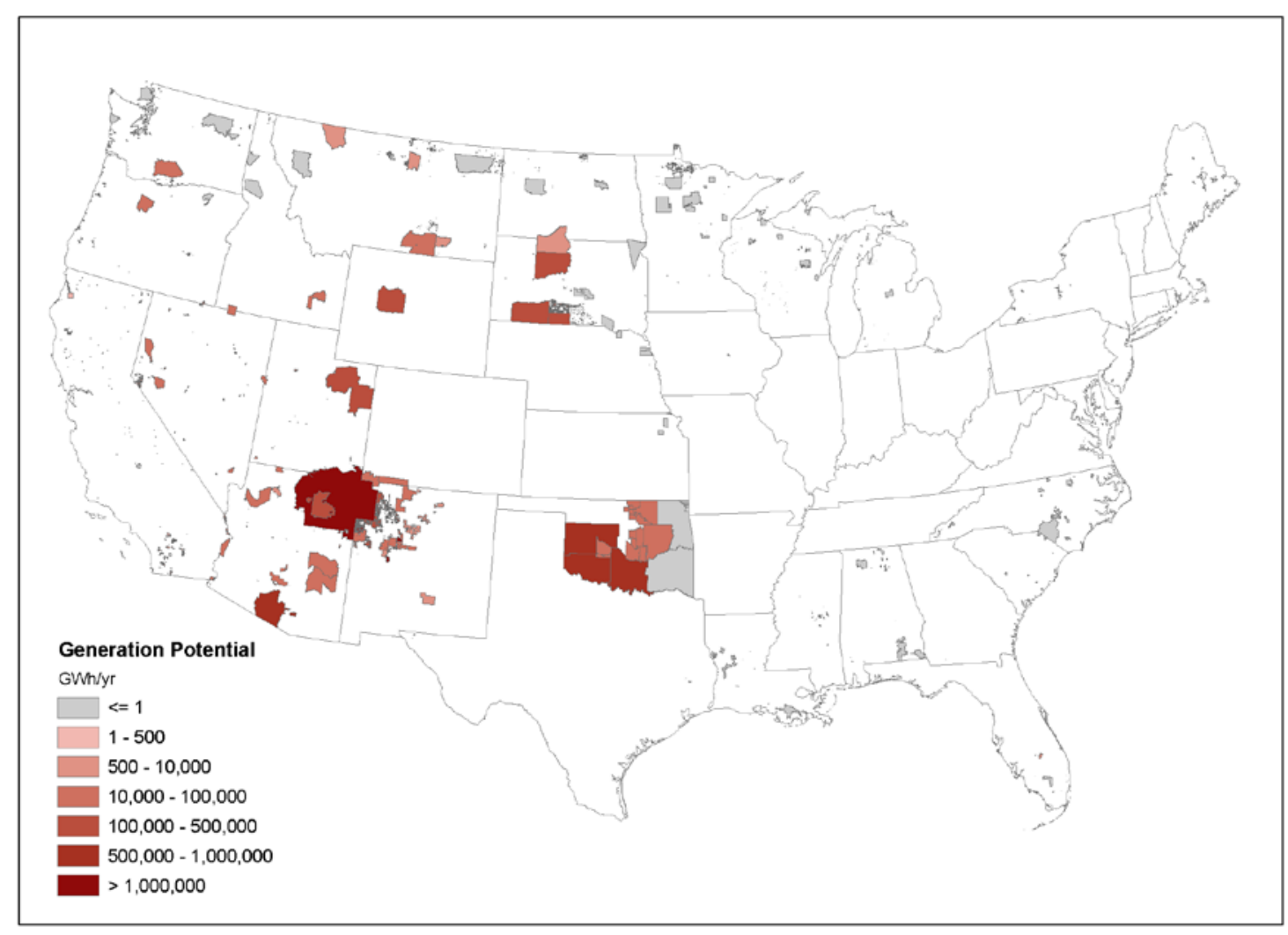

Figure 6. Concentrating solar power generation potential by reservation 


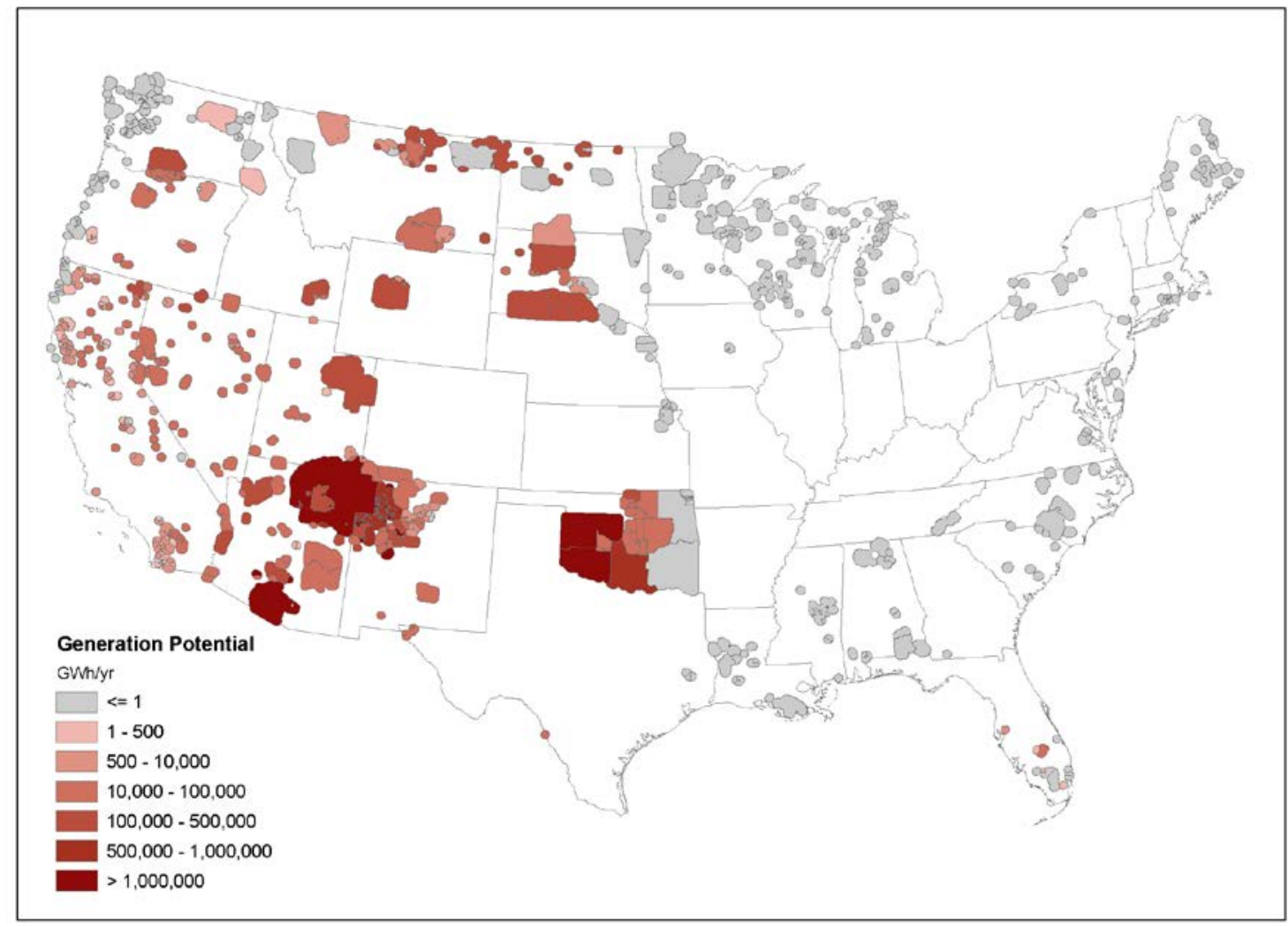

Figure 7. Concentrating solar power generation potential by reservation (including extended areas of 10 miles adjacent to the tribal land boundaries) 
Table 9. Fifteen Tribal Lands with the Highest Technical Potential for Concentrating Solar Power Electricity Generation

\begin{tabular}{|c|c|c|c|c|}
\hline Tribal Area & State & $\begin{array}{l}\text { Net } \\
\text { Generation } \\
\text { (MWh) }\end{array}$ & $\begin{array}{l}\text { Capacity } \\
\text { (MW) }\end{array}$ & $\begin{array}{l}\text { Available } \\
\text { Land Area } \\
\left(\mathbf{k m}^{2}\right)\end{array}$ \\
\hline Navajo & Arizona & $1,953,959,322$ & 462,886 & 23,806 \\
\hline $\begin{array}{l}\text { Kiowa-Comanche-Apache-Fort } \\
\text { Sill Apache OTSA }\end{array}$ & Oklahoma & $830,492,318$ & 262,618 & 13,506 \\
\hline Cheyenne-Arapaho OTSA & Oklahoma & $807,778,806$ & 255,435 & 13,137 \\
\hline Tohono O'odham & Arizona & $686,027,362$ & 161,827 & 8,323 \\
\hline Chickasaw OTSA & Oklahoma & $559,018,460$ & 176,773 & 9,091 \\
\hline Hopi & Arizona & $259,499,142$ & 60,227 & 3,097 \\
\hline Pine Ridge & South Dakota & $235,508,182$ & 74,472 & 3,830 \\
\hline Uintah and Ouray & Utah & $199,351,312$ & 52,982 & 2,725 \\
\hline $\begin{array}{l}\text { Navajo Off-Reservation Trust } \\
\text { Land }\end{array}$ & Arizona & $175,386,888$ & 42,047 & 2,162 \\
\hline Wind River & Wyoming & $132,807,983$ & 41,268 & 2,122 \\
\hline Cheyenne River & South Dakota & $129,875,385$ & 41,069 & 2,112 \\
\hline Rosebud & South Dakota & $109,666,172$ & 34,679 & 1,783 \\
\hline Gila River & Arizona & $97,322,280$ & 23,332 & 1,200 \\
\hline $\begin{array}{l}\text { Caddo-Wichita-Delaware } \\
\text { OTSA }\end{array}$ & Oklahoma & $77,964,977$ & 24,654 & 1,268 \\
\hline $\begin{array}{l}\text { Citizen Potawatomi-Absentee } \\
\text { Shawnee OTSA }\end{array}$ & Oklahoma & $72,205,787$ & 22,833 & 1,174 \\
\hline
\end{tabular}

\section{Biomass}

Various biomass resources are available in the United States that are processed into electricity, heat, fuels, and chemicals. These resources include (1) lignocellulosic material (plant biomass that is composed of cellulose, hemicellulose, and lignin) such as woody biomass and crop residues; (2) lipids such as vegetable oils, waste oils, and animal fats; (3) sugar or starch-based crops; and (4) wet organic waste such as wastewater sludge, food waste, and animal manure. This study focuses on estimating the power generation potential from woody biomass and biogas (from wet organic waste) on tribal lands. Woody biomass is the main resource used for biopower generation in the United States, while the use of agricultural crop residues is insignificant (Warner et al. 2017). Biogas potential is examined because of its rising capacity in recent years: landfill gas supplied approximately $18 \%$ of total U.S. biopower generation in 2015, an increase from 9.5\% in 2003 (Warner et al. 2017).

The focus of this analysis is on dedicated, utility-scale biopower potential from woody biomass and distributed biogas potential. For additional analysis, future work may estimate the heat generation potential from biomass (e.g., pellets production) because those applications are better suited for on-site feasibility studies in which local resources and market conditions can be examined in more detail. Future work may also investigate the combined heat and power 
potential from biomass sources, the potential for alternative transportation fuels production, or biochar for applications such as soil amendment and remediation.

\section{Woody Biomass}

\section{Data Information}

The woody biomass material considered in this study includes the following types.

\section{Forest Residues}

Forest residues include logging residues and other removable material left after silviculture operations and site conversions. Logging residue comprises unused portions of trees that were cut or killed by logging and left in the woods. Other removable materials are the unused trees cut or killed during logging operations. The database used in this analysis illustrates $65 \%$ of logging residues and $50 \%$ of other removals, which is the portion that could be collected as biomass. The remaining portion is to be left on the field to maintain ecological functions. Data were gathered from the U.S. Department of Agriculture Forest Service Timber Product Output Database for 2012.

\section{Primary Mill Residues}

Primary mill residues include wood materials (coarse and fine) and bark generated at manufacturing facilities (primary wood-using mills) when round wood products are processed into primary wood products, such as slabs, edgings, trimmings, sawdust, veneer clippings and cores, and pulp screenings. Note that most of this resource is currently used on site to offset facilities' energy consumption. Data were gathered from the U.S. Department of Agriculture Forest Service Timber Product Output Database for 2012.

\section{Secondary Mill Residues}

Secondary mill residues include wood scraps and sawdust from woodworking shops—-furniture factories, wood container and pallet mills, and wholesale lumberyards. Data on the number of businesses by county were gathered from the U.S. Census Bureau's 2012 County Business Patterns and further processed to estimate the amount of secondary mill residues by county.

\section{Urban Wood Waste}

Urban wood waste includes wood material from municipal solid waste (such as wood chips and pallets), utility tree trimming and/or private tree companies, and construction and demolition sites. Data from the U.S. Census Bureau (2012 population data and County Business Patterns) and BioCycle (2010) were used and further processed to estimate the amount of urban wood waste by county.

Note that woody biomass data for Alaska are very limited. The state has vast forest resources, and information on the total forest biomass is available (Alaska Energy Authority 2016; U.S. Forest Service 2011); however, limited data exist on the amount of resources that could be sustainably harvested, such as forest and primary mill residues, which are the focus of this study. Therefore, the estimates for biopower potential in Alaska villages should be considered partial. It is reasonable to assume that the biopower potential in those locations is larger than estimated here. 


\section{Analysis Methodology}

The U.S. Geological Survey 2011 National Land Cover Database 30-meter land use and land cover data set was used to disaggregate the county-level woody biomass resource estimates to the subcounty level. The 2011 National Land Cover Database is the most recent national and spatially resolved land cover data set created by the Multi-Resolution Land Characteristics Consortium (Homer et al. 2015). Using the National Land Cover Database as the disaggregation unit, we identified and paired each biomass resource type with its most appropriate corresponding land cover value (Table 10). Biomass resource values were then proportionally allocated to the tribal lands based on the total percentage area of resource (land cover type) intersecting the tribal lands within a given county. Final tribal estimates are the summation of their intersecting county estimates.

Table 10. Biomass Resource and Land Cover Pairings

\begin{tabular}{|c|c|c|}
\hline $\begin{array}{l}\text { Land Cover } \\
\text { Type }\end{array}$ & Woody Biomass Resource & $\begin{array}{l}\text { National Land Cover Database Multi- } \\
\text { Resolution Land Characteristics } \\
\text { Consortium Raster Values }\end{array}$ \\
\hline Forest & $\begin{array}{l}\text { Forest residues } \\
\text { Primary mill residues }\end{array}$ & $\begin{array}{l}\text { Deciduous forest } \\
\text { Evergreen forest } \\
\text { Mixed forest }\end{array}$ \\
\hline Urban & $\begin{array}{l}\text { Urban wood waste } \\
\text { Secondary mill residues }\end{array}$ & $\begin{array}{l}\text { Developed, low intensity } \\
\text { Developed, medium intensity } \\
\text { Developed, high intensity }\end{array}$ \\
\hline
\end{tabular}

The technical potential for bioenergy generation is calculated by assuming 1.1 MWh per dry tonne, which represents an average solid biomass system output with an industry-average conversion efficiency of $20 \%$ and a high heating value of $8,500 \mathrm{Btu} / \mathrm{lb}$ (Lopez et al. 2012). Also, this analysis assumes that all biomass resources considered were available for biopower, and it did not evaluate competing uses such as heat applications or biofuels production.

\section{Results}

Table 11 illustrates the results of this analysis and summarizes the woody biomass power generation and capacity potential on tribal lands. Significantly more woody biomass is available within the extended areas. The 10-mile radius is illustrative-in general, biomass resources could be collected within a 50-mile radius to keep the transportation cost reasonable; thus, the biopower potential under the extended scenario could be even higher. Figure 8 and Figure 9 illustrate the woody biomass power generation potential by reservation and within the extended areas, and Table 12 shows the 15 tribal lands with the highest technical potential for biopower generation.

According to the Alaska Energy Authority, more than 999,800 tons of wood are burned in the form of cordwood, chips, and pellets annually (Alaska Energy Authority 2016). Our limited database for woody biomass (which would be the equivalent of chips) indicates that approximately 365,000 dry tons are produced in the state annually. 
Table 11. Woody Biomass Power Generation and Capacity Potential on Tribal Lands

\begin{tabular}{lll}
\hline Scenario & $\begin{array}{l}\text { Generation } \\
\text { (MWh) }\end{array}$ & $\begin{array}{l}\text { Capacity } \\
\text { (MW) }\end{array}$ \\
\hline Tribal lands & $2,472,201$ & 542 \\
Expanded tribal lands & $16,786,866$ & 3,678 \\
\hline
\end{tabular}

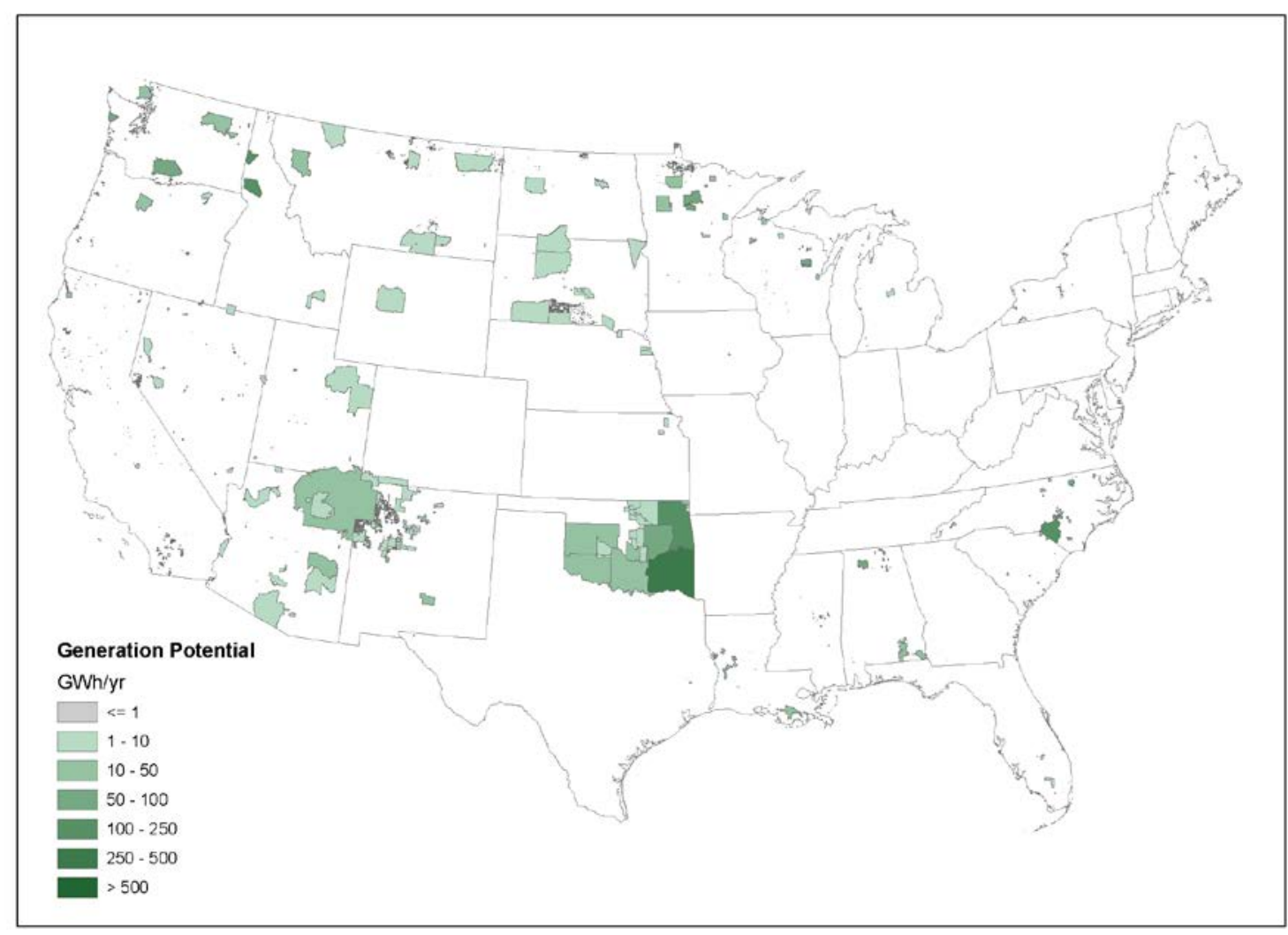

Figure 8. Biopower generation potential by reservation 


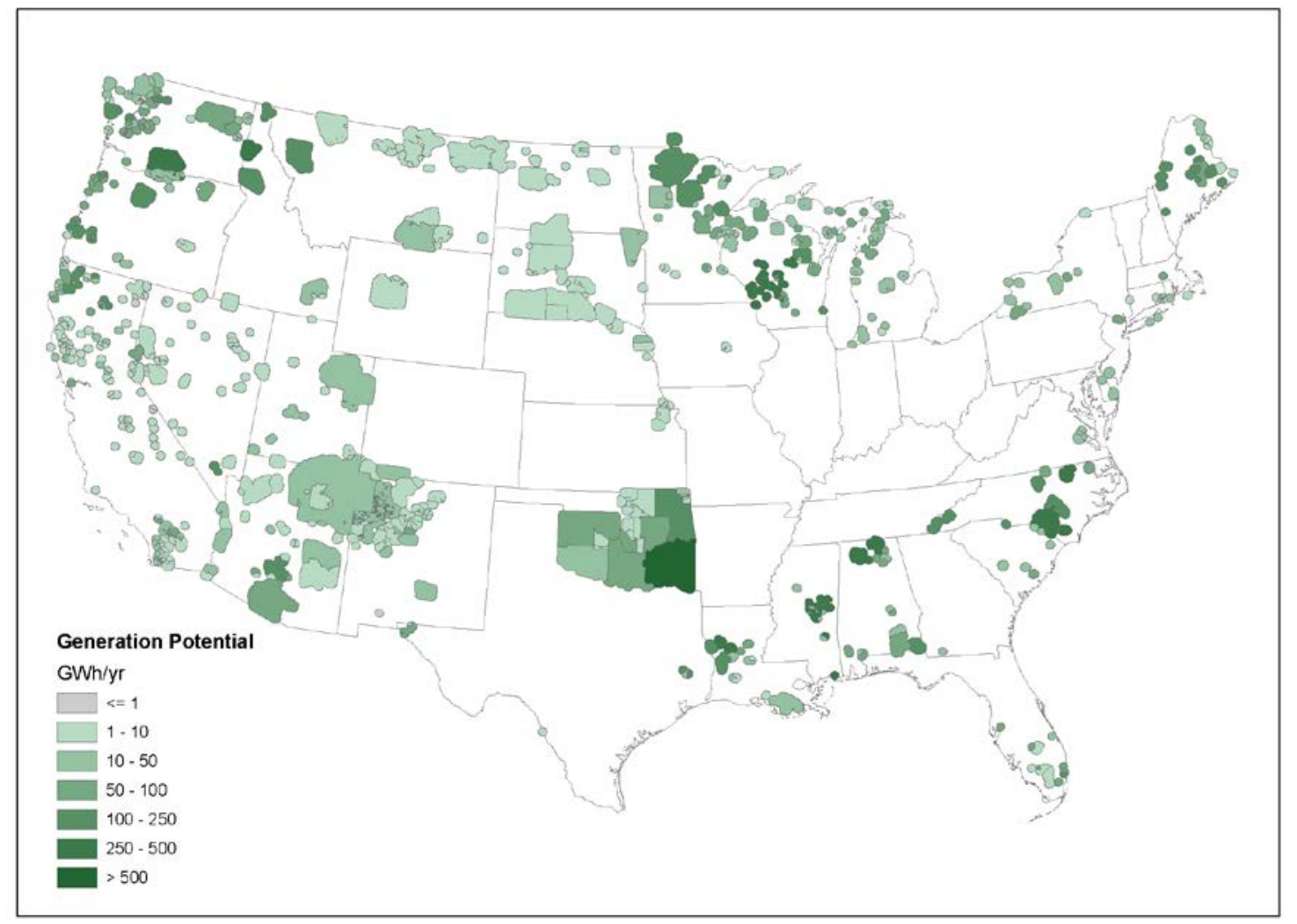

Figure 9. Biopower generation potential by reservation (including extended areas of 10 miles adjacent to the tribal land boundaries) 
Table 12. Fifteen Tribal Lands with the Highest Technical Potential for Biopower Generation from Woody Biomass Sources

\begin{tabular}{llll}
\hline Tribal Area & State & $\begin{array}{l}\text { Net } \\
\text { Generation } \\
\text { (MWh) }\end{array}$ & $\begin{array}{l}\text { Capacity } \\
\text { (MW) }\end{array}$ \\
\hline Choctaw OTSA & Oklahoma & 446,235 & 98 \\
Coeur d'Alene Reservation & Idaho & 140,250 & 31 \\
Lumbee SDTSA & North Carolina & 121,055 & 27 \\
Nez Perce Reservation & Idaho & 118,971 & 26 \\
Cherokee OTSA & Oklahoma & 111,857 & 25 \\
Creek OTSA & Oklahoma & 97,611 & 21 \\
Quinault Reservation & Washington & 96,688 & 21 \\
Yakama Nation Reservation & Washington & 89,925 & 20 \\
Haliwa-Saponi SDTSA & North Carolina & 83,507 & 18 \\
Menominee Reservation & Wisconsin & 60,221 & 13 \\
Echota Cherokee SDTSA & Alabama & 59,539 & 13 \\
Leech Lake Reservation & Minnesota & 56,873 & 12 \\
Chickasaw OTSA & Oklahoma & 41,745 & 9 \\
Adais Caddo SDTSA & Louisiana & 41,030 & 9 \\
Warm Springs Reservation & Oregon & 38,573 & 8 \\
\hline
\end{tabular}

\section{Distributed-Scale Discussion}

Distributed biomass power generation systems can range from less than $1 \mathrm{MW}-50 \mathrm{MW}$, depending on the amount of available biomass resources (Patel 2012). The most common biomass generators at the distributed scale make use of the power plants' waste heat to provide needed thermal energy, which allows projects to be economically viable (NREL 2016). In the United States, most combined heat and power systems are installed in large industrial facilities that have significant electrical and thermal loads as well as significant waste streams (such as lumber or paper mills) that serve as free fuels that would otherwise incur a disposal cost (NREL 2016).

Gasification is another conversion technology well suited for small-scale biopower applications. It is a thermo-chemical process that converts organic material through partial oxidation into an energy-rich gas (syngas) that can fuel steam generators, combustion turbines, combined-cycle technologies, or fuel cells. There are, however, technical challenges regarding gas cleanup and ash problems that limit the development of this technology. More research is needed to overcome the technical barriers of biomass gasification for further commercialization.

\section{Biogas}

Biogas is the gaseous product of anaerobic digestion, a biological process in which microorganisms break down biodegradable material in the absence of oxygen. Biogas is comprised of primarily methane and carbon dioxide and might have some amounts of other 
elements, such as water, nitrogen, hydrogen, and ammonia. Biogas via anaerobic digestion is produced from various sources, such as organic landfill waste, animal manure, wastewater sludge, and waste from food-processing industries. Biogas can also be produced from lignocellulosic material through thermochemical conversions, such as gasification, but most biogas in the United States and globally is produced via anaerobic digestion of organic waste. With minor cleanup (e.g., siloxane removal), biogas is used to generate electricity and heat. To fuel vehicles, biogas must be processed to a higher purity standard. This process is called conditioning or upgrading, and it involves the removal of water, carbon dioxide, hydrogen sulfide, and other trace elements. The resulting gas, also called biomethane or renewable natural gas, has a higher content of methane than raw biogas, which makes it comparable to conventional natural gas and, thus, a suitable energy source in applications that require pipelinequality gas. This study focuses on evaluating the biogas potential via anaerobic digestion from organic waste for electricity generation.

\section{Data Information}

This study includes the following biogas sources.

\section{Wastewater}

Wastewater is rich in organic matter, and anaerobic digestion is often used to reduce sludge (the untreated solids that remain after wastewater processing) as part of sludge management at wastewater treatment facilities. In recent years, more treatment facilities use the produced biogas on-site in heat and power applications. Data on the volume of wastewater flow at each treatment facility (approximately 15,000 across the United States) were gathered from the U.S. Environmental Protection Agency’s 2012 Clean Watersheds Needs Survey (2017a).

\section{Animal Manure}

Manure is an organic material containing nitrogen, phosphorus, potassium, and other nutrients. Land application is the most common disposal pathway for this material, but more livestock operations are implementing on-site power plant energy recovery via anaerobic digestion. Data on the number of heads and volume of manure produced at dairy, beef, and swine concentrated feeding operations across the United States (more than 32,000 locations) were provided by Timothy Seiple (Personal communication, March 2017) and Milbrandt et al. (2018).

\section{Organic Landfill Waste}

The organic portion of solid waste disposed in landfills (e.g., food and yard waste) decomposes to form biogas. The biogas from landfills is generally called landfill gas because of the digestion process taking place in the ground rather than in an anaerobic digester. Data on the landfill locations and amount of waste were gathered from the U.S. Environmental Protection Agency's Landfill Methane Outreach Program (U.S. Environmental Protection Agency 2017b). Note that only "candidate" landfills are included in this study, not existing landfill gas projects. The outreach program defines a candidate landfill as one that is accepting waste or has been closed for 5 years or less; has at least 1 million tons of waste; and does not have an operational, underconstruction, or planned project. Candidate landfills can also be designated based on actual interest in the site. Note that as of March 2017, there were 407 candidate landfills in the country; however, only 250 of those locations had the detailed data necessary for our analysis. Therefore, the landfill gas estimate should be considered partial. 


\section{Analysis Methodology}

The analysis methodology for estimating the biogas potential from wastewater and organic landfill waste is adopted from Saur and Milbrandt (2014), and the methodology for estimating biogas potential from animal manure is derived from Fulhage, Sievers, and Fischer et al. (2017) and briefly described here. Given that methane is the usable portion of biogas, estimates are shown as methane potential and subsequently converted to electricity generation potential.

The biogas potential from wastewater is estimated to be approximately 1 cubic foot per 100 gallons of wastewater, and methane is assumed to be $65 \%$ by volume. The annual methane potential is calculated as shown in Equation 1: Annual methane potential for wastewater:

annual methane potential $(\mathrm{kg} / \mathrm{yr})$

$$
=q * \frac{1 \mathrm{ft}^{3} \text { biogas }}{100 \text { gal wastewater }} * \frac{0.0283 \mathrm{~m}^{3} \text { biogas }}{\mathrm{ft}^{3} \text { biogas }} * \frac{65 \% \mathrm{~m}^{3} \mathrm{CH}_{4}}{\mathrm{~m}^{3} \text { biogas }} * \frac{.662 \mathrm{kgCH}}{\mathrm{m}^{3} \mathrm{CH}_{4}}
$$

where $\mathrm{q}$ is the wastewater flow in gallons per year.

The biogas potential from organic landfill waste is estimated to be approximately 300 standard cubic feet per minute of landfill gas per 1 million tons of waste-in-place, and methane is assumed to be $50 \%$ by volume. The landfill gas generation is affected by whether the site is closed or if new waste is being accepted-it is not a steady quantity over time. For open candidate landfills, the waste-in-place data are normalized to the year 2016 by taking the waste-in-place in the recorded year, different for each record, and adding additional years of waste based on the annual waste acceptance rate of the site up to the year 2016. For closed candidate landfills, the waste-in-place was calculated similarly to the open landfills, but additional years of waste are added only up to the year the site closed. Only landfills that closed within the last 5 years were included in this analysis. The annual methane potential is then calculated as shown in Equation 2: Annual methane potential equation for organic landfill waste:

annual methane potential (tonnes/yr)

$$
=W I P * \frac{300 \mathrm{scfm} L F G}{1 \mathrm{MM} \text { tons } W I P} * \frac{50 \% \mathrm{CH}_{4}}{L F G} * \frac{0.0423 \mathrm{lb} / \mathrm{min}}{1 \mathrm{scfm}} * \frac{525,600 \mathrm{~min}}{y r} * \frac{\text { tonne }}{2204.62 \mathrm{lb}}
$$

where WIP is waste-in-place in million tons of waste in 2016 for open landfills and for the year closed for closed landfills.

The biogas potential from manure is estimated for each animal type, and it assumes that methane is $60 \%$ by volume. The annual methane potential is calculated as shown in Equation 3: Annual methane potential equation for animal manure:

$$
\text { annual methane potential (tonnes } / y r)=N * \mathrm{~K} * 365 * \frac{60 \% f t^{3} \mathrm{CH}_{4}}{f t^{3} \text { biogas }} * \mathrm{p} * \frac{\text { tonne }}{2204.62 \mathrm{lb}}
$$

where $\mathrm{N}$ = head count, $\mathrm{K}$ = potential biogas production in cubic feet per animal unit per day (dairy: 22.7, beef: 31, and swine: 4.1 ), and $\mathrm{p}=$ density of methane [0.0413 lb/ $\left.\mathrm{ft}^{3}\right]$. 
The technical potential for electricity generation from biogas sources is calculated by assuming 4.7 MWh/tonne of methane, which represents a typical gaseous biomass system output with an industry-average conversion efficiency of $30 \%$ and a high heating value of $24,250 \mathrm{Btu} / \mathrm{lb}$ (Lopez et al. 2012).

\section{Results}

Table 13 illustrates the results of this analysis and summarizes the power generation and capacity potential from biogas on tribal lands. Figure 10 and Figure 11 illustrate the power generation potential from biogas by reservation and within the extended areas, and Table 14 shows the 15 tribal lands with the highest technical potential for biogas electricity generation. Many reservations have good biogas potential from the sources examined here, but this potential is significantly higher if tribes consider expanding their lands to surrounding areas. Note that biogas estimates are site-specific and were aggregated to reservation level for mapping purposes.

Table 13. Biogas Generation and Capacity Potential on Tribal Lands

\begin{tabular}{ll}
\hline Technical Potential & $\begin{array}{l}\text { Net Generation } \\
\text { (MWh) }\end{array}$ \\
\hline Tribal area & 391,591 \\
Expanded tribal area & $2,701,106$ \\
\hline
\end{tabular}

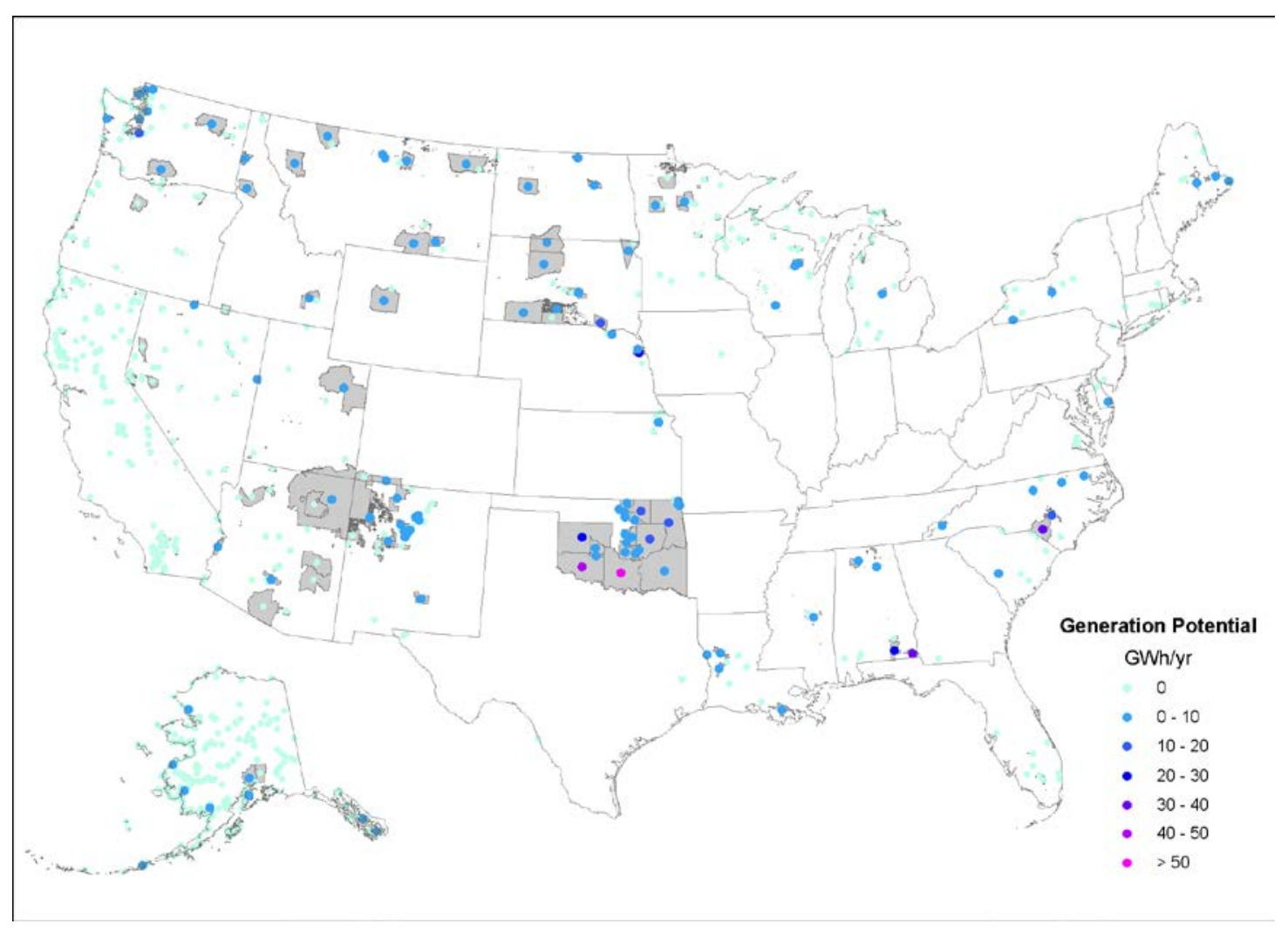

Figure 10. Biogas power generation potential by reservation 


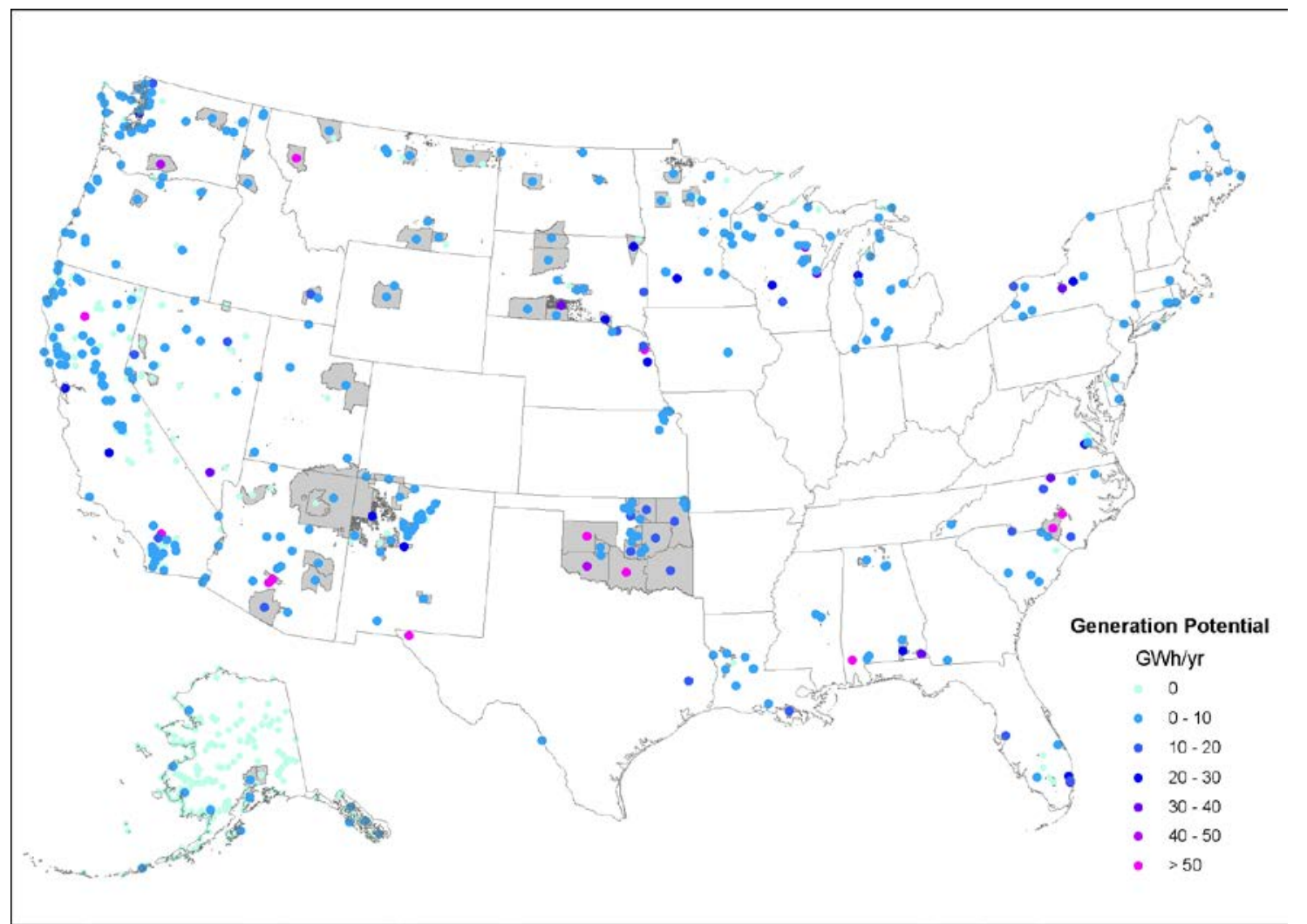

Figure 11. Biogas power generation potential by reservation (including extended areas of 10 miles adjacent to the tribal land boundaries) 
Table 14. Fifteen Tribal Lands with the Highest Technical Potential for Biogas Power Generation

\begin{tabular}{lll}
\hline Tribal Area & State & Net Generation (MWh) \\
\hline $\begin{array}{l}\text { Chickasaw OTSA } \\
\text { Kiowa-Comanche-Apache-Fort Sill Apache }\end{array}$ & Oklahoma & 61,217 \\
OTSA & Oklahoma & 43,699 \\
Cher-O-Creek SDTSA & Alabama & 38,104 \\
Lumbee SDTSA & North Carolina & 33,742 \\
Cheyenne-Arapaho OTSA & Oklahoma & 29,608 \\
Omaha & Nebraska & 23,417 \\
MaChis Lower Creek State Designated Tribal & & \\
Statistical Area (SDTSA) & Alabama & 22,997 \\
Creek OTSA & Oklahoma & 17,961 \\
Yankton & South Dakota & 16,872 \\
Cherokee OTSA & Oklahoma & 15,157 \\
Osage & Oklahoma & 14,536 \\
Puyallup & Washington & 13,533 \\
Coharie SDTSA & North Carolina & 11,549 \\
Choctaw OTSA & Oklahoma & 6,756 \\
Winnebago & Nebraska & 4,610 \\
\hline
\end{tabular}

\section{Food Waste Discussion}

Food waste refers to food that is fit for human consumption but is not consumed because it is left to spoil or discarded by retailers or consumers (Food and Agriculture Organization of the United Nations 2017). Food waste is another resource for biogas production, usually co-digested with other material, such as wastewater sludge, but it could be digested separately as well. Food waste comes from various sources: industrial (e.g., food processors), institutional (e.g., hotels, hospitals), commercial (e.g., restaurants and supermarkets) and residential, as well as at point of production (power plants).

The main food waste generation sources on tribal lands are casinos. There are approximately 486 Indian gaming operations in the United States (500 Nations 2017; Indian Gaming 2017; National Indian Gaming Commission 2017); however, not all have restaurants on-site-our research indicates that approximately 394 locations have at least one restaurant on-site (Figure 12). The rest of the operations might have some limited food services on-site, but they are too small to be considered candidates for biogas generation. 


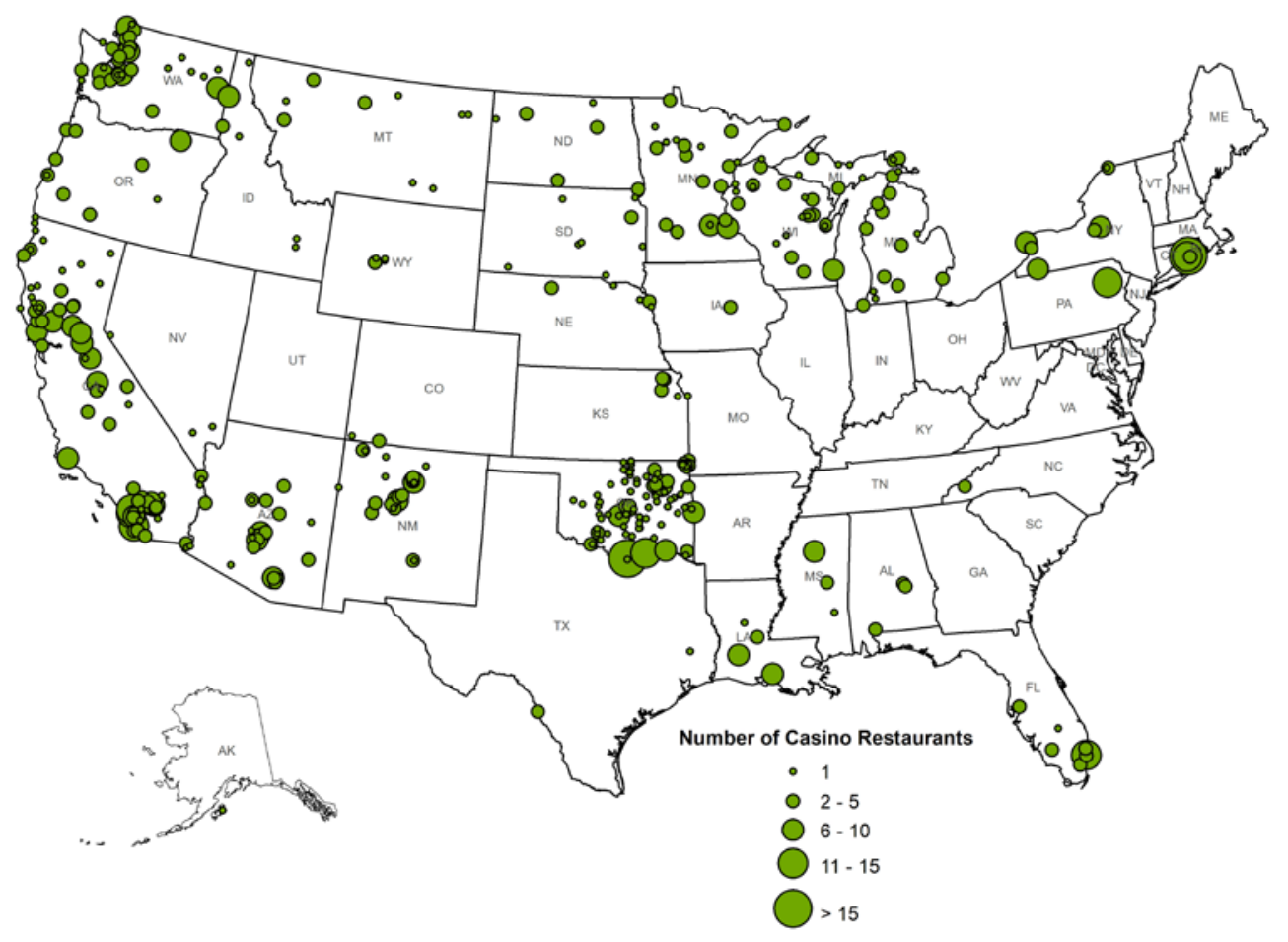

Figure 12. Casinos with restaurants on tribal lands

A single restaurant can produce approximately $25,000-75,000 \mathrm{lb}$ (12.5-37.5 tons) of food waste in 1 year (Business Insider 2016). Our research indicates that there are approximately 1,077 restaurants at tribal casinos; thus, the amount of food waste that is generated annually could be between 13,500 tons and 40,000 tons. This amount corresponds to approximately 756-2,300 tonnes of methane, or 3.6-11 GWh of electricity. Because of a lack of data, we are unable to estimate the biogas potential from food waste at each casino. Without detailed on-site information, estimates would be misleading because each location varies in terms of restaurant size, number of seats, number of employees, hours of operation, etc. For reference, almost half of the casinos (48\%) have one restaurant on-site (some could be small or very large), approximately $19 \%$ have more than five restaurants, and less than 3\% have more than 10 restaurants. Casinos with a small amount of food waste can provide it to nearby larger casinos, or tribes can collect the food waste from all casinos on their lands to achieve optimum biogas generation potential and minimize waste disposal.

\section{Geothermal (Hydrothermal)}

Geothermal energy harnesses the heat content of the earth and converts it to electricity. There are several ways to access this heat content. This analysis considers only hydrothermal resources. These geothermal reservoirs of steam or hot water occur naturally where magma comes close enough to the surface to heat ground water trapped in fractured or porous rocks or where water circulates deep along faults (University of Colorado Boulder 2017). Hydrothermal resources are used for different energy purposes depending on their temperature and depth. Previous technical potential analyses for tribal lands also included estimates for enhanced geothermal systems (engineered geothermal systems, as an alternative to natural convective hydrothermal resources, 
that recover geothermal heat from dry hot rocks), but this technology is not included here because it is still developing and unlikely to be feasible for near-term development opportunities.

\section{Data Information}

The sites used in this analysis have been characterized by the United States Geological Survey (Williams et al. 2008), and development of the data set included an evaluation of nearby potential exclusionary conditions. Additionally, the nature of geothermal energy extraction allows broad flexibility in siting the geothermal facility; it can be located outside of protected areas, and energy can be extracted laterally through the hot water reservoirs. Given these considerations, no additional technical exclusions were applied to the identified geothermal sites.

\section{Analysis Methodology}

The published U.S. Geological Survey data set includes characterization of the temperature resource, potential installed capacity, and a representative location for the identified resource site. This information was used in this analysis, but it was modified to account for geothermal capacity that has already been developed at a site.

\section{Results}

Table 15 illustrates the results of this analysis and summarizes the hydrothermal generation and capacity potential on tribal lands. Figure 13 and Figure 14 illustrate the geothermal generation potential by reservation and within the extended areas. Only three identified geothermal sites fall within the tribal boundaries directly (Table 16), and an additional 23 sites are identified within the expanded tribal area.

Table 15. Geothermal Generation and Capacity Potential on Tribal Lands

\begin{tabular}{lll}
\hline Scenario & $\begin{array}{l}\text { Generation } \\
\text { (MWh) }\end{array}$ & $\begin{array}{l}\text { Capacity } \\
\text { (MW) }\end{array}$ \\
\hline Tribal lands & 228,251 & 33 \\
Expanded tribal lands & $3,558,943$ & 508 \\
\hline
\end{tabular}




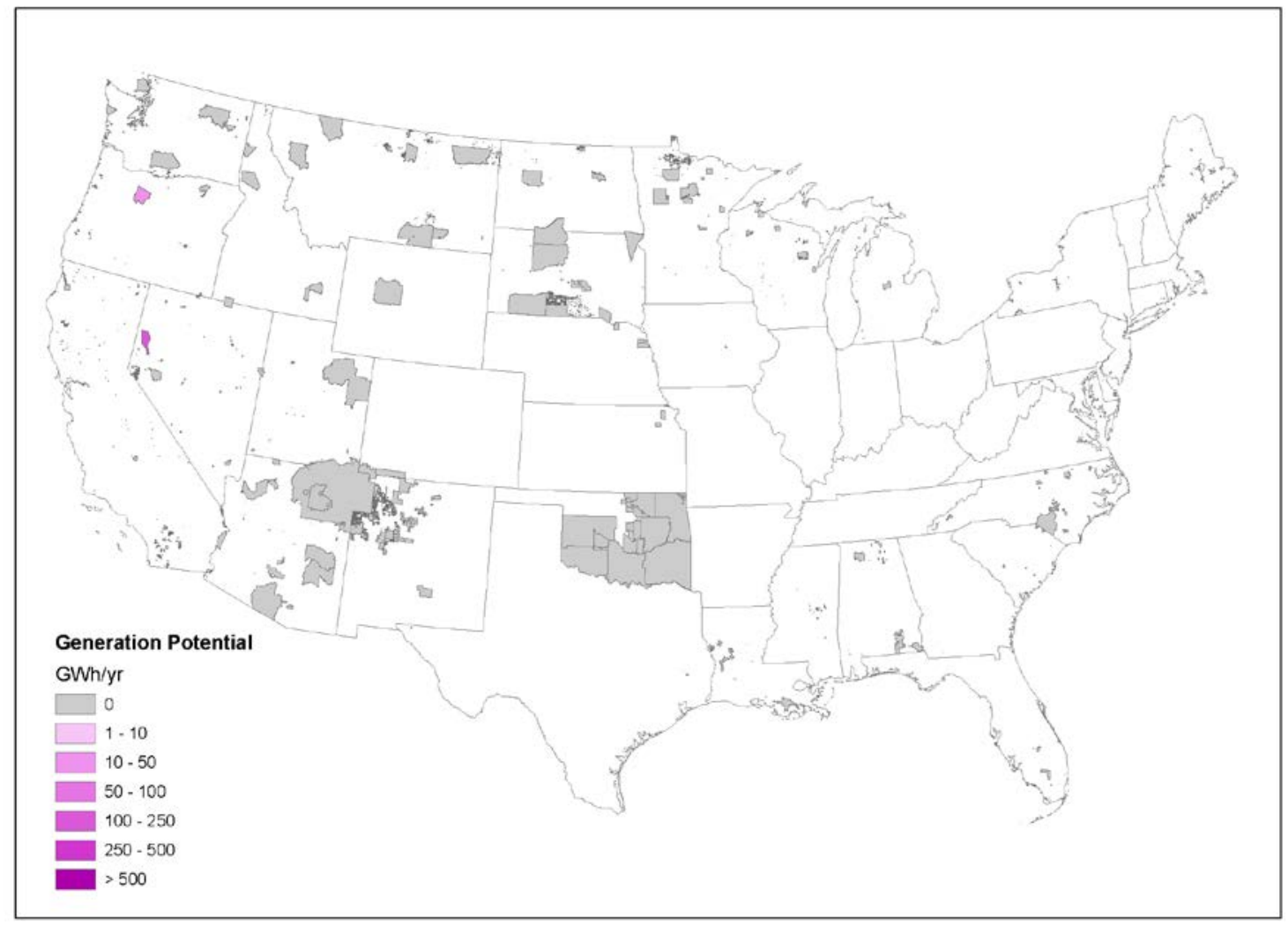

Figure 13. Geothermal generation potential by reservation 


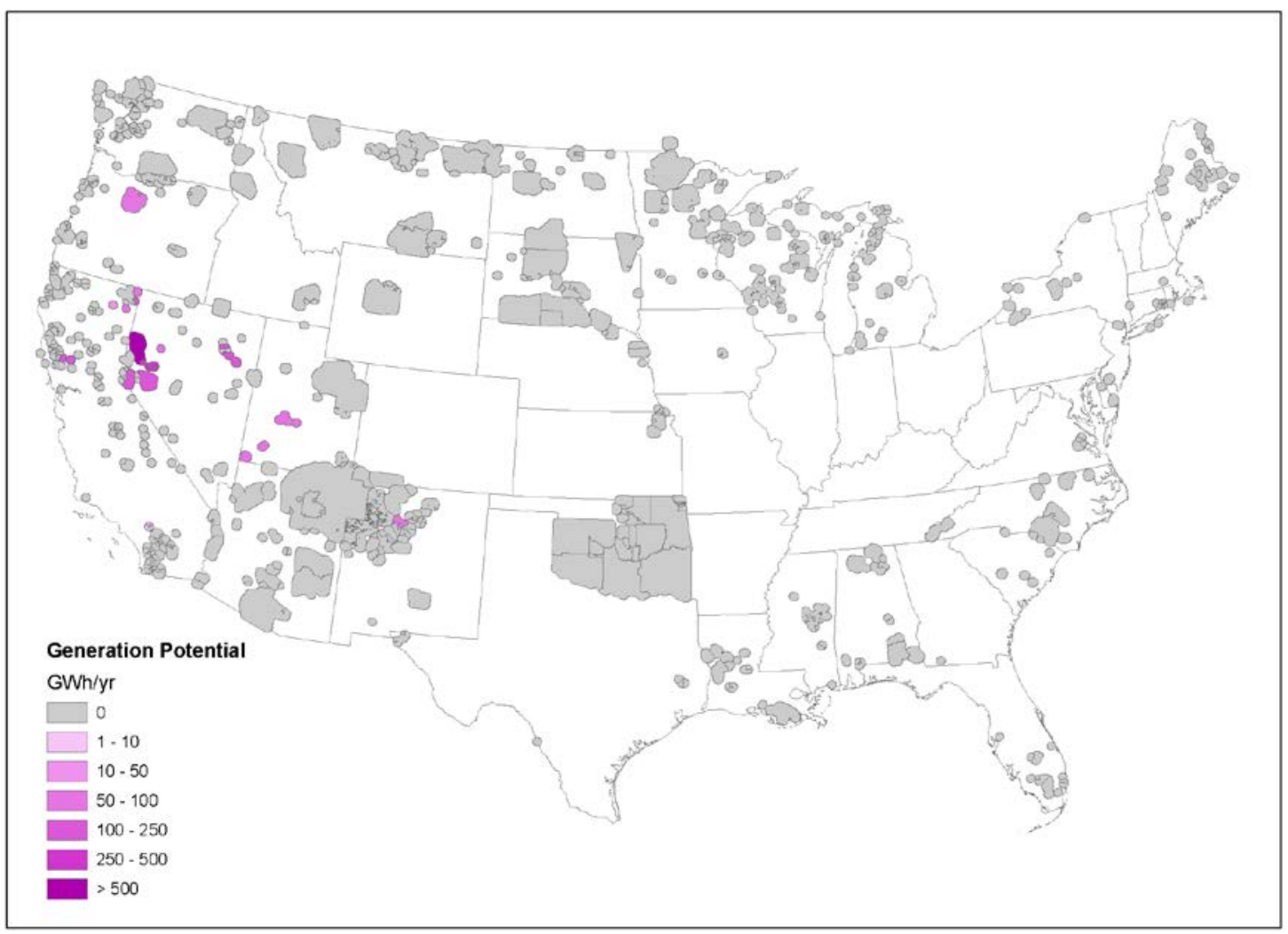

Figure 14. Geothermal generation potential by reservation (including extended areas of 10 miles adjacent to the tribal land boundaries)

Table 16. Tribal Lands with the Highest Technical Potential for Geothermal Electricity Generation

\begin{tabular}{llll}
\hline Tribal Area & State & $\begin{array}{l}\text { Net Generation } \\
\text { (MWh) }\end{array}$ & $\begin{array}{l}\text { Capacity } \\
\text { (MW) }\end{array}$ \\
\hline Pyramid Lake Paiute & Nevada & 121,729 & 17 \\
Fort Bidwell & California & 64,053 & 9 \\
Warm Springs & Oregon & 42,468 & 6 \\
\hline
\end{tabular}

\section{Hydropower}

Hydropower energy is extracted from the kinetic energy of flowing water. In many cases, natural systems are enhanced or manipulated by creating impoundments (dams) to increase the amount of water flow or water drop height. Hydropower is one of the oldest sources of energy for producing mechanical and electrical energy (U.S. Energy Information Administration [EIA] 2017a). Because the source of hydroelectric power is water, hydroelectric power facilities are located on or near a water source (EIA 2017a).

\section{Data Information}

This analysis uses modeled hydropower resource data created by Oak Ridge National Laboratory for new stream-reach potential (Kao et al. 2014), and Oak Ridge National Laboratory published an analysis of the potential that could be extracted from existing nonpowered dams (Hadjerioua, 
Wei, and Kao 2012). The nonpowered dams are represented by a point location; the new streamreach data are represented as a polygonal area containing a stream segment being modeled.

\section{Analysis Methodology}

\section{Technical Potential Exclusions}

The analysis was completed separately for each hydro resource data set. No technical potential exclusions were applied to the nonpowered dams because these are existing hydropower installations to which energy extraction is being added. For the new stream-reach resource data set, the analysis excluded areas that fell completely within environmental areas that would be limited to development (i.e., parks and wilderness areas). However, many of the stream-reach polygons that intersected excluded areas intersected only in part and would need further evaluation to determine if there is usable potential within the unexcluded area and if the usable potential falls within the tribal areas.

\section{Technology Characterization}

The technology characterization was included in the Oak Ridge National Laboratory's published resource data sets. Our analysis directly used their values for potential site capacity and system performance.

\section{Results}

Table 17 illustrates the results of this analysis and summarizes the hydropower generation and capacity potential on tribal lands. Figure 15 and Figure 16 illustrate the hydropower generation potential by reservation and within the extended areas, and Table 18 shows the 15 tribal lands with the highest technical potential for hydropower electricity generation.

Regionally there is significant hydropower potential on tribal lands throughout the country, except for the dry portions of the Southwest and parts of the Great Plains.

Table 17. Hydropower Generation and Capacity Potential on Tribal Lands

\begin{tabular}{lll}
\hline Scenario & $\begin{array}{l}\text { Generation } \\
\text { (MWh) }\end{array}$ & $\begin{array}{l}\text { Capacity } \\
\text { (MW) }\end{array}$ \\
\hline Tribal lands & $124,511,610$ & 21,420 \\
Expanded tribal lands & $225,331,062$ & 39,280 \\
\hline
\end{tabular}




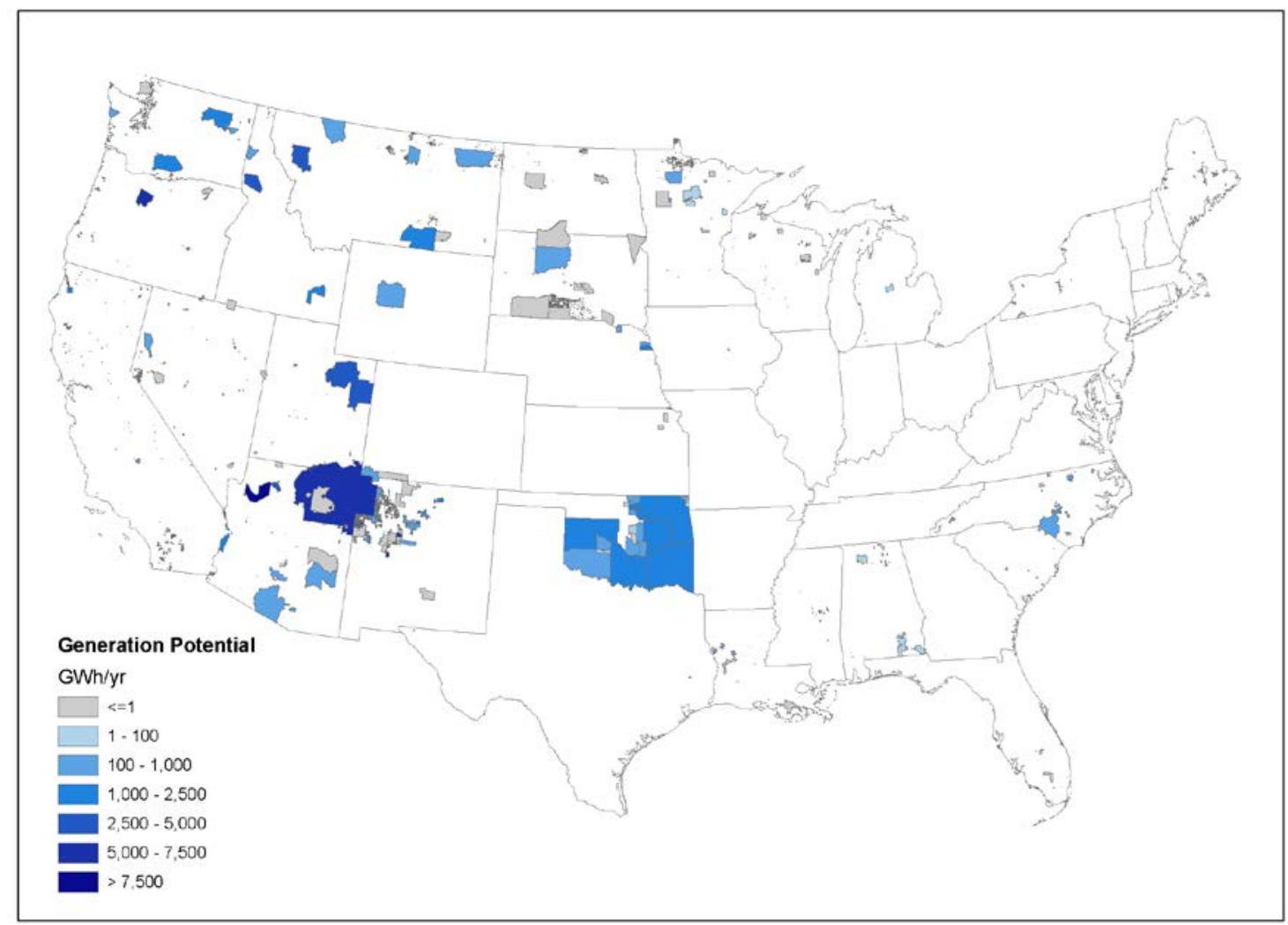

Figure 15. Hydropower generation potential by reservation 


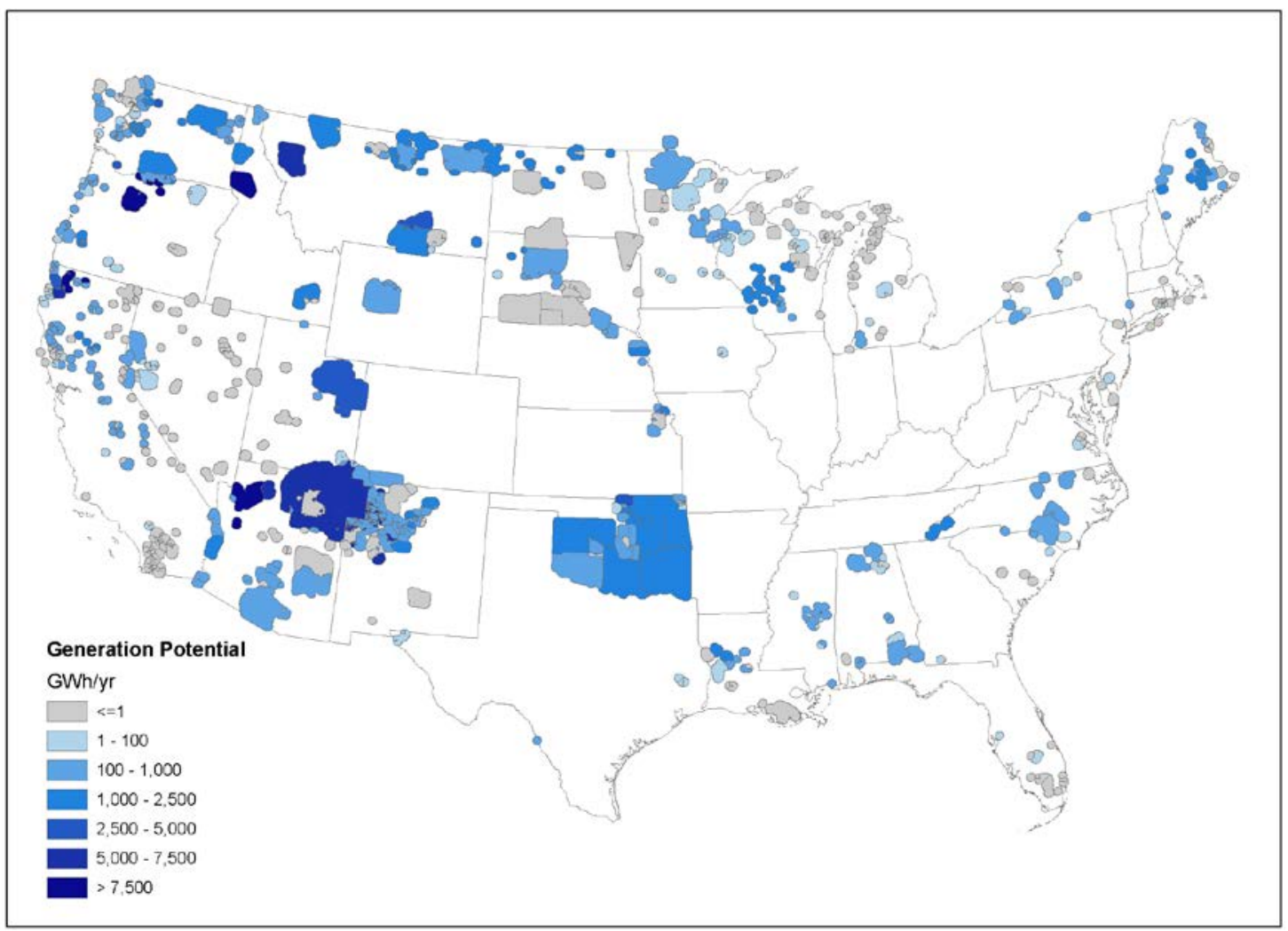

Figure 16. Hydropower generation potential by reservation (including extended areas of 10 miles adjacent to the tribal land boundaries) 
Table 18. Fifteen Tribal Lands with the Highest Technical Potential for Hydropower Generation

\begin{tabular}{|c|c|c|c|}
\hline Tribal Area & State & $\begin{array}{l}\text { Net Generation } \\
\text { (MWh) }\end{array}$ & $\begin{array}{l}\text { Capacity } \\
\text { (MW) }\end{array}$ \\
\hline Hualapai & Arizona & $8,528,986$ & 1,357 \\
\hline $\begin{array}{l}\text { Warm Springs Off- } \\
\text { Reservation Trust Land }\end{array}$ & Oregon & $7,519,818$ & 1,027 \\
\hline Warm Springs & Oregon & $7,126,821$ & 968 \\
\hline Navajo & Arizona & $5,593,783$ & 920 \\
\hline $\begin{array}{l}\text { Karuk Off-Reservation Trust } \\
\text { Land }\end{array}$ & California & $4,389,193$ & 831 \\
\hline Nez Perce & Idaho & $4,180,255$ & 776 \\
\hline Flathead & Montana & $3,550,559$ & 580 \\
\hline Uintah and Ouray & Utah & $3,066,532$ & 537 \\
\hline $\begin{array}{l}\text { Crow Off-Reservation Trust } \\
\text { Land }\end{array}$ & Montana & $2,827,420$ & 471 \\
\hline Havasupai & Arizona & $2,553,209$ & 407 \\
\hline Yurok & California & $2,356,901$ & 461 \\
\hline Hoopa Valley & California & $2,348,371$ & 459 \\
\hline Osage & Oklahoma & $2,115,399$ & 409 \\
\hline Cherokee OTSA & Oklahoma & $2,057,204$ & 492 \\
\hline Choctaw OTSA & Oklahoma & $2,013,322$ & 415 \\
\hline
\end{tabular}

\section{Distributed-Scale Discussion}

Smaller hydropower systems typically do not involve any impoundments or diversions of the natural stream but instead rely on run-of-the-river systems to extract energy. Systems can be quite small, $<1 \mathrm{MW}$ in size. The resource data sets used in this analysis do not resolve these smaller potential systems. 


\section{Utility-Scale Economic Potential}

As shown in the preceding analysis, there is a vast amount of renewable energy technical potential on tribal lands in the United States. Technical potential does not factor economic criteria for developing renewable energy. Most decisions regarding energy strategies, however, are made not only on what is technically possible but also according to what is economically favorable. This chapter applies a basic economic screen to analyze the subset of total technical potential for tribal lands that might be of actual commercial interest.

\section{Data Information}

Two principal data sets are used in this analysis: NREL's ATB (2017) and regional electricity market price estimates compiled in Brown et al. (2016). These data sources are discussed below with a brief listing of other assumptions used.

Levelized cost of energy (LCOE) is a critical metric in this analysis to represent the all-in cost of an energy technology. ${ }^{4}$ The LCOE for a given technology is estimated from capital, operations and maintenance, and financing costs reported in the ATB (NREL 2017). The mid-cost case values are used. Capital and operation and maintenance cost estimates for hydropower and geothermal, however, are derived from the U.S. Department of Energy Hydropower Vision Study and forthcoming Geothermal Vision Study (DOE 2016; DOE forthcoming). Table 19 presents the assumptions for the capital costs, operation and maintenance expenditures, and financing rates. ${ }^{5}$ The energy generation estimates required to calculate LCOE are based on the results of the technical potential analysis.

\footnotetext{
${ }^{4}$ The LCOE incorporates all the estimated costs during a project's lifetime-including upfront costs, ongoing maintenance expenditures, financing charges, and fuel costs (if any) — which are then divided by the total amount of energy generation estimate. The resulting LCOE estimate provides a levelized cost per unit of energy and is typically reported in either cents per kilowatt-hour or dollars per megawatt-hour.

${ }^{5}$ The capital cost estimates for utility-scale PV are based on a one-axis tracking system, which is assumed to be representative of most types of utility-scale PV applications. Similarly, for biopower the capital cost assumptions reflect a fuel source specifically harvested and designed for electricity generation purposes. A range of capital cost estimates are used for land-based wind and hydropower, however, to account for technology design variations such as wind speed or head height, and given the relatively small number of the geothermal projects identified on tribal land, the capital cost estimates are based on a site-specific estimate from the Geothermal Vision Study (DOE forthcoming).
} 
Table 19. Overview of Renewable Energy Technology Cost Assumptions

\begin{tabular}{llll}
\hline Technology & $\begin{array}{l}\text { Capital Costs } \\
\text { (\$/kW) }\end{array}$ & $\begin{array}{l}\text { Operation and } \\
\text { Maintenance } \\
\text { (\$/kW/year) }\end{array}$ & Financing Rate \\
\hline Biopower & $\$ 3,701$ & $\$ 108$ & $9.02 \%$ \\
Geothermal & $\$ 11,981-\$ 16,422$ & $\$ 341-\$ 461$ & $9.02 \%$ \\
Hydropower & $\$ 3,895-\$ 6,567$ & $\$ 13$ & $9.02 \%$ \\
Land-based Wind & $\$ 1,573-\$ 1,713$ & $\$ 50$ & $9.02 \%$ \\
Utility-scale PV & $\$ 1,219$ & $\$ 12$ & $9.02 \%$ \\
\hline
\end{tabular}

Source: NREL 2017

The second critical input is the levelized avoided cost of energy (LACE) based on regional wholesale market electricity prices. ${ }^{6}$ LACE is an important input variable because it represents a project's estimated revenue from electricity sales. Projects with higher LACE tend to draw more commercial interest than projects with lower LACE values.

Currently, no centralized data source captures the market price of electricity on a uniform basis across the United States. Brown et al. (2016) used a patchwork of sources to determine wholesale electricity price data across the United States. The market price estimates used to estimate LACE are illustrated in Figure 17. Brown et al. (2016) account for possible future electric market price increases through the year 2034 by applying an annual energy price escalator from the EIA’s 2014 Annual Energy Outlook Reference Case Price Projections and "levelized to an effective present price.” Brown et al. (2016) prices are converted to 2015 U.S. dollars to be consistent with the 2017 ATB data.

This analysis also adjusts the Brown et al. (2016) market price estimate downward to reflect lower natural gas and wholesale power prices since the 2014 data year. EIA (2017b) reports that natural gas prices for electricity production declined from \$5.29/MMbtu in 2014 to \$3.59/Mmbtu through August 2017. The change in natural gas prices is then converted to changes in wholesale electricity prices. Hurlbut et al. (2016) use a statistical analysis to compare natural gas prices to wholesale electricity prices and report that every dollar change in natural gas price was estimated to impact wholesale power prices by \$6.73/MWh-\$8.77/MWh in the same direction. ${ }^{7}$ Applying the national price decline in natural gas for power production reported by the EIA in 2017 with the wholesale power price conversion from Hurlbut et al. (2016) results in a reduction to the base wholesale power price of approximately $\$ 13 / \mathrm{MWh}$. The $\$ 13 / \mathrm{MWh}$ reduction is applied to the LACE price estimates reported in Brown et al. (2016).

\footnotetext{
${ }^{6}$ In this analysis, LACE represents the available revenue to a project in \$/MWh. The EIA developed the LACE metric, and Brown et al. (2016) describes it as follows: "The LACE metric captures available revenue to a renewable energy project at a specific location in terms of displaced energy and displaced capacity."

${ }^{7}$ Hurlbut et al. (2016) conducted this statistical analysis specific to the Mead Hub in the southwestern United States. This relationship is extended to the rest of the United States for this simplified analysis; however, each trading hub and market is likely to have a unique interplay between natural gas prices and wholesale power prices. Another simplifying assumption made here is adopting a simple average between off-peak and on-peak power prices.
} 


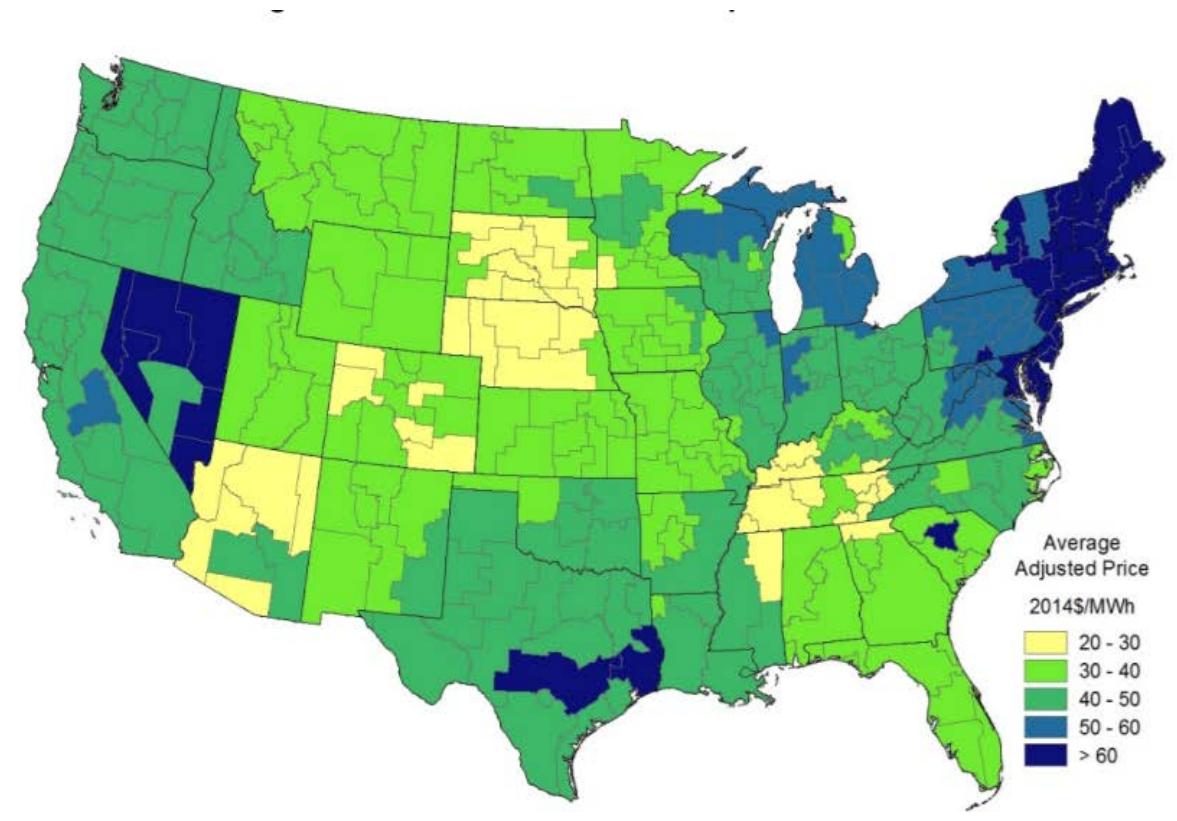

Figure 17. Market price estimate with projected price changes from 2014-2034 and levelized to an effective current price ${ }^{8}$

Source: Brown et al. 2016

This analysis also incorporates the following other assumptions and considerations:

- A 10\% investment tax credit is assumed for utility-scale PV and geothermal technologies. Unlike other tax incentives, they currently do not have a stated expiration date and therefore are used to represent the long-term federal tax credit policy. ${ }^{9}$

- Accelerated depreciation ${ }^{10}$ is assumed for all technologies that do not have currently a stated expiration date.

- Tribes are able to partner with a taxable entity to efficiently use and benefit from taxbased incentives. ${ }^{11}$

- Other state policies (e.g., state renewable portfolio standards), environmental considerations (e.g., carbon dioxide emissions), and tribal preferences are not factored into the analysis.

\footnotetext{
${ }^{8}$ Brown et al. (2016) note higher than average wholesale market prices in Nevada and Texas that persist in this analysis. These higher than average prices might prove to be relative outliers over the long term and should be revisited with future analyses.

${ }^{9}$ This analysis was conducted prior to the passage of the Tax Cut and Jobs Act of 2017 that among other changes lowered the corporate tax rate. The impact of the legislation on renewable energy and tribal developed is not settled and is thus identified as an area of future analysis refinement.

${ }^{10}$ Note that the 5-year Modified Accelerated Cost Recovery System is assumed for accelerated depreciation.

${ }^{11}$ This generally refers to a tribal entity that benefits from the renewable energy tax incentives, which can be difficult and costly for smaller projects with limited tax appetite.
} 


\section{Analysis Methodology}

The basic framework for estimating economic potential for a given energy technology compares the estimated cost of renewable energy to the reported LACE prices in the regional electricity markets. Projects are considered as showing economic potential when the LACE (i.e., the revenue) is more than the $\mathrm{LCOE}$ (i.e., the costs). For example, in the illustrative Scenario 1 below, the renewable energy shows economic potential because the LACE is more than the LCOE. Conversely, in Scenario 2, tribal renewable energy for a specific technology does not show economic potential because the LACE is less than the LCOE.

- $\quad$ Scenario 1: Regional LACE > tribal LCOE = economic potential identified

- Scenario 2: Regional LACE < tribal LCOE = no economic potential identified.

The approach to estimating economic potential by comparing the LCOE of renewable energy to the LACE is described thoroughly in Brown et al. (2016). The methodology used herein to calculate the economic potential on tribal lands generally follows the methodology established in Brown et al. (2016), although several simplifying assumptions are made. ${ }^{12}$ Calculating the tribal economic potential methodology follows the following conceptual steps.

1. The technical potential for renewable energy is calculated for each reservation following the methodology described in this report.

2. For each reservation, the LCOE is estimated for the identified available renewable energy technologies, including biopower, geothermal, hydropower, land-based wind, and solar PV.

3. The LACE is calculated for each reservation based on the data shown in Figure 17.

4. The economic potential is determined for each reservation by comparing the estimated LACE and LCOE components.

The economic potential analysis is limited to the renewable energy technologies typically developed at the utility scale. Typically, utility-scale generation projects sell output in regional electricity markets instead of using it on-site or locally. Technologies that are primarily used to offset local load — such as distributed PV, biogas, and certain hydroelectric facilities - are not included here because of data and scope limitations; however, they are discussed briefly in the next section. ${ }^{13}$

\section{Caveats}

It is important to qualify this analytical approach. There are many specific inputs for estimating the economic potential of a technology in a location and the actual project values might differ substantially from the assumptions used here. In the Results section, a limited scenario analysis

\footnotetext{
${ }^{12}$ For more information on economic potential including how the methodology was established, a description of the underlying data sources and calculations and a comprehensive set of instructions and caveats are available in Brown et al. (2016).

${ }^{13}$ Some data requirements for this analysis include load profiles for generalized tribal building types (administration building, casinos, etc.) and utility-specific rate structures including tier and seasonal factors, demand charges, and time-of-use schedules. These data and more would be needed to estimate energy savings as a measure of economic potential. Distributed solar PV, for example, typically offsets only energy-based charges, not demand-based charges; therefore, a basic rate structure is required to delineate between the two.
} 
illustrates the high sensitivity of the economic potential to different input assumptions. Some caveats to this approach include:

- Energy projects on tribal lands very likely have different cost profiles than the national benchmarks used in the 2017 ATB.

- Inherent site-specific cost factors might not be fully captured, including infrastructure access and suitability (roads, transmissions, etc.), local labor laws, unusual site challenges, deal-specific lease and royalty terms, and uncertain or changing tribal, federal, state, and local energy policies.

- Federal tax credits targeted to renewable energy may possibly be changed, modified, or canceled.

- Environmental attributes and the value they might capture during the life of the project are not considered.

- This analysis focuses on the site LCOE and does not include estimates for intra-regional transmission costs. ${ }^{14}$ This assumes that tribal projects and nearby nontribal projects experience the same transmission access and costs.

- The capacity value of each energy generation technology is not included here. This possible revenue stream is not considered for this analysis because capacity markets are not universally available across the United States, and because of analysis scope limitations.

- Similarly, the declining value of variable renewable energies as their overall penetration on the grid increases is also not considered here, although it was a parameter in Brown et al. $(2016){ }^{15}$

- The actual future trajectory of renewable energy costs as well as the overall market prices of electricity might vary significantly from the assumptions used here.

Because of these limitations and caveats, along with many other factors, these economic potential estimates should be considered as case-specific rather than precise.

\section{Results}

Table 20 presents the results of the renewable energy economic potential on tribal lands in the 48 contiguous states for the set of utility-scale technologies considered here. The results illustrate the economic potential in total capacity (GW) and annual generation (TWh). The results indicate a sizeable amount of tribal economic potential for land-based wind and utility-scale PV. Other

\footnotetext{
${ }^{14}$ As described later, the inclusion of intra-regional transmission is a noted area for follow-on activities. Brown et al. (2016) note an average cost of approximately \$7-\$8/MWh for intra-regional transmission, but they acknowledge that this is likely a high-cost estimate because in many cases existing transmission might be used, shared with other regions, or provided by the energy purchaser. This busbar-based LCOE provides an initial economic assessment, and sites with economic potential would be further analyzed to evaluate the likely transmission costs. These costs are generally location-, technology- and project-specific.

${ }^{15}$ For more information on why renewable energy sources might decrease in value with increased penetration levels, see Mills and Wiser (2012).
} 
renewable technologies did not show positive economic potential on tribal lands based on the set of assumptions used here.

Consistent with the technical potential findings, utility-scale PV shows the greatest economic potential-approximately $61 \mathrm{GW}$, which equates to approximately $116 \mathrm{TWh}$ of electricity generation annually. The economic potential for land-based wind exceeds $1 \mathrm{GW}$ and 3 TWh annually. Most of the economic potential in this analysis is concentrated in high LACE areas, such as Nevada (see note 10). Assuming an average installed price of $\$ 1,219 / \mathrm{kW}$ and $\$ 1,573 / \mathrm{kW}$ for solar and wind, respectively, this economic potential would represent more than $\$ 75$ billion in project investment.

Table 20. Estimated Tribal Economic Potential for the 48 Contiguous States at Utility Scale Based on Site Levelized Cost of Energy

\begin{tabular}{|c|c|c|c|c|c|c|c|c|c|}
\hline \multicolumn{2}{|c|}{ Biopower } & \multicolumn{2}{|c|}{ Geothermal } & \multicolumn{2}{|c|}{ Hydropower } & \multicolumn{2}{|c|}{ Land-Based Wind } & \multicolumn{2}{|c|}{ Utility-Scale PV } \\
\hline GW & TWh & GW & TWh & GW & TWh & GW & TWh & GW & TWh \\
\hline 0 & 0 & 0 & 0 & 0 & 0 & 1 & 3 & 61 & 116 \\
\hline
\end{tabular}

The economic potential is then examined under different natural gas price scenarios. The analysis examined 2014-2017 natural gas prices for electricity production, which ranged from a high price of $\$ 7.18 / \mathrm{Mmbtu}$ to a low price of $\$ 2.45 / \mathrm{Mmbtu}{ }^{16}$ The conversion ratio to wholesale prices as described in the Data Information section is similarly applied here. For the high price sensitivity, the economic potential for utility-scale PV rose to approximately 266 GW (523 TWh annually), and land-based wind rose to more than 142 GW (506 TWh annually). For the recent low natural gas price sensitivity, utility-scale PV stayed nearly the same, at 61 GW (115 TWh annually); whereas land-based wind fell to $0.2 \mathrm{GW}$ (0.6 TWh annually). These variations demonstrate the importance of determining economic competitiveness under a range of future electricity cost scenarios that can also be extended to future renewable energy costs.

The results illustrate that of all the technical potentials identified, a subset of sites would likely hold enough economic potential to be examined in more depth for additional inputs such as transmission cost and interest of potential energy buyers. Conversely, projects that do not show economic potential initially will likely be revisited as the relative costs of renewable energy and market prices change.

${ }^{16}$ Based on a three-month average price. 


\section{Distributed Generation Economic Indicators}

An evaluation of the LCOE for distributed wind, residential PV, biogas, and small-scale hydropower is presented here. The technology cost assumptions are presented in Table 21, and they are taken from NREL's 2017 ATB. No regional cost adjustments are included, which can be a significant component of total costs for distributed generation projects.

Distributed wind and PV potential exists for every tribal area; however, in low-resource areas, the resulting LCOE is high and unlikely to be competitive with grid electricity prices (Figure 18 and Figure 19). Wind performance was determined for a $50 \mathrm{~m}$ hub height. Costs used are for a 100-kW-1-MW wind turbine, and they are summarized to show the best LCOE for each tribal area. PV performance for a fixed flat-plate collector with tilt equal to the latitude was used, modeled with PVWatts, and LCOE results are shown for the best sites in each tribal area. The LCOE maps show the best LCOE results estimated for each tribal area. Actual LCOEs will be determined by the resource at the site being developed, and site-specific costs are not captured in this simplified calculation.

Not all tribal areas will have biogas or small hydropower potential. The LCOE for biogas was assumed to be equal to the regional natural gas price (Daniel Inman, personal communication, June 2017). A small hydropower resource was extracted from the utility-scale hydropower analysis, limited to systems with a capacity of 1-5 MW. Smaller systems are likely for distributed hydropower, but they are not included in this assessment. In Alaska, a hydropower resource data set showing previously published information by Idaho National Laboratory was used to assess whether potential existed near tribal areas, but LCOE was not calculated because the data lacked capacity factor estimates. The spatial distribution of the LCOEs for biogas and hydropower are shown in Figure 20 and Figure 21, and they are summarized for all technologies in Table 22.

Table 21. Overview of Renewable Energy Technology Cost Assumptions (2015 U.S. Dollars)

\begin{tabular}{llll}
\hline Technology & $\begin{array}{l}\text { Capital Costs } \\
\mathbf{( \$ / k W )}\end{array}$ & $\begin{array}{l}\text { Operation and } \\
\text { Maintenance } \\
\mathbf{( \$ / k W / y e a r )}\end{array}$ & Financing Rate \\
\hline $\begin{array}{l}\text { Small-scale } \\
\text { hydropower }\end{array}$ & $\$ 5,614-\$ 7,269$ & $\$ 31-\$ 112$ & $9.02 \%$ \\
$\begin{array}{l}\text { Distributed wind } \\
\text { 2 }\end{array}$ & $\begin{array}{l}\$ 2,346-\$ 7,645 \\
(\$ 3,751 \text { in results) }\end{array}$ & $\$ 31-40$ & $9.02 \%$ \\
${\text { Residential } \mathrm{PV}^{1}}^{1}$ & $\$ 2,800$ & $\$ 21$ & $9.02 \%$ \\
\hline
\end{tabular}

Source: NREL 2017; NREL 2016. 
Table 22. Distributed Generation Range of Levelized Cost of Energy ${ }^{a}$

\begin{tabular}{ll}
\hline Technology & LCOE $(\$ / \mathbf{k W h})$ \\
\hline Biogas $^{\mathrm{b}}$ & $\$ 0.01-\$ 0.02$ \\
$\begin{array}{l}\text { Small-scale } \\
\text { hydropower }\end{array}$ & $\$ 0.10-\$ 0.20$
\end{tabular}

Distributed wind $\quad \$ 0.40-\$ 41.70^{c}$

Residential PV \$0.11-\$0.33

${ }^{a}$ LCOE is based on the closest natural gas price hub.

${ }^{b}$ Biogas is assumed to be at parity with natural gas prices.

${ }^{\mathrm{c}}$ High LCOE value represents a very low wind resource site, estimated to have $<1 \%$ annual capacity factor.

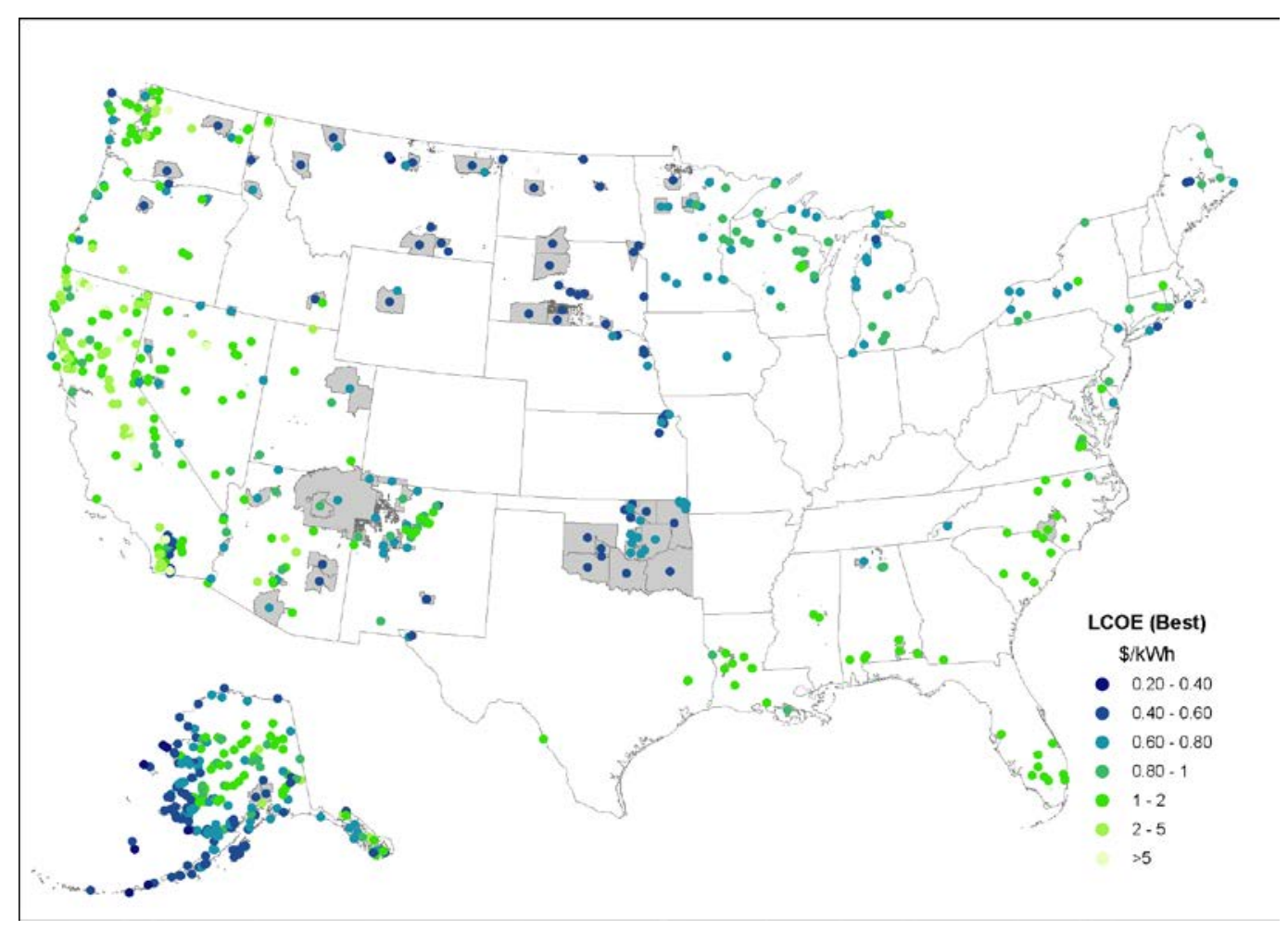

Figure 18. Potential distributed wind levelized cost of energy in tribal areas 


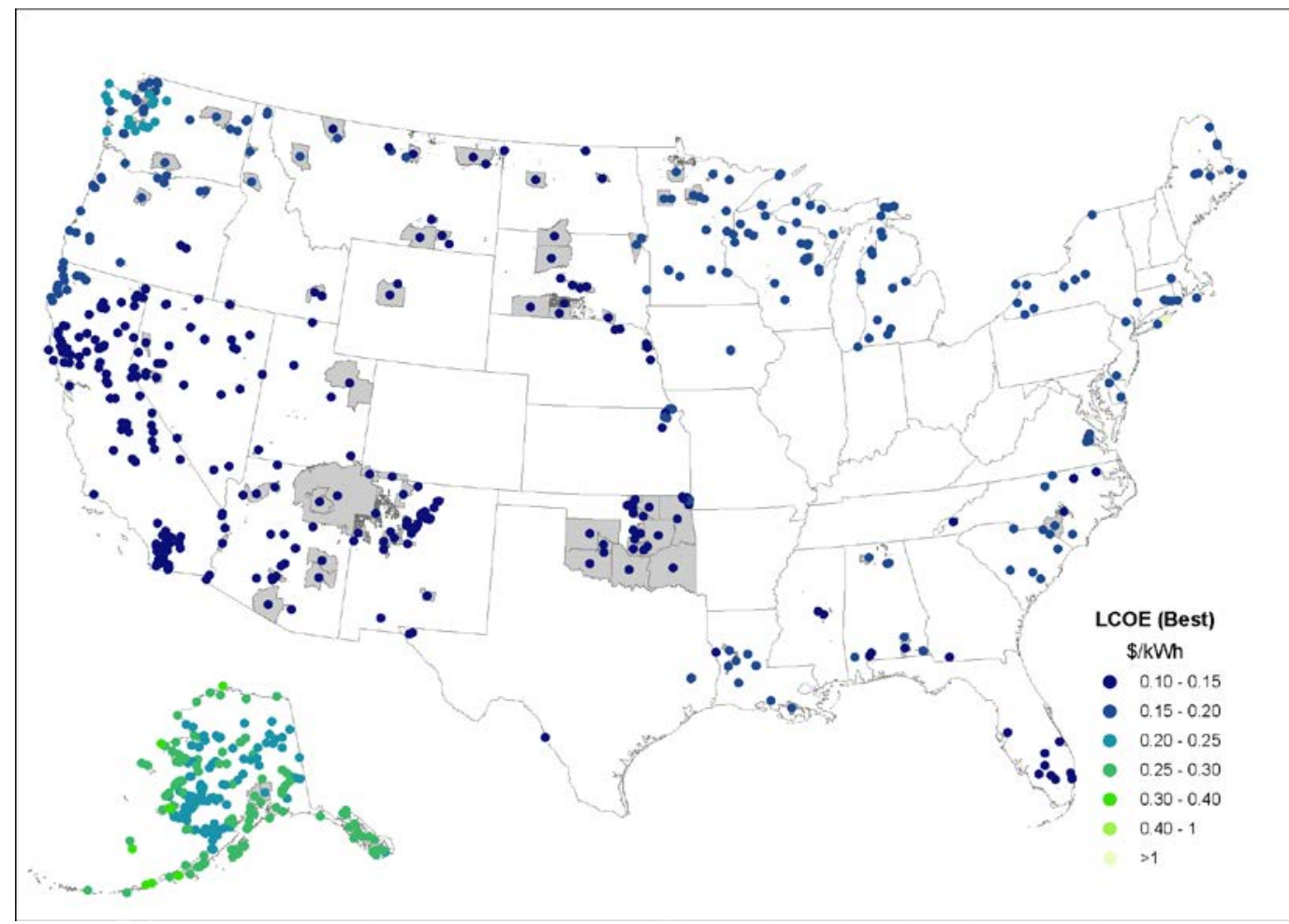

Figure 19. Potential distributed photovoltaic levelized cost of energy in tribal areas

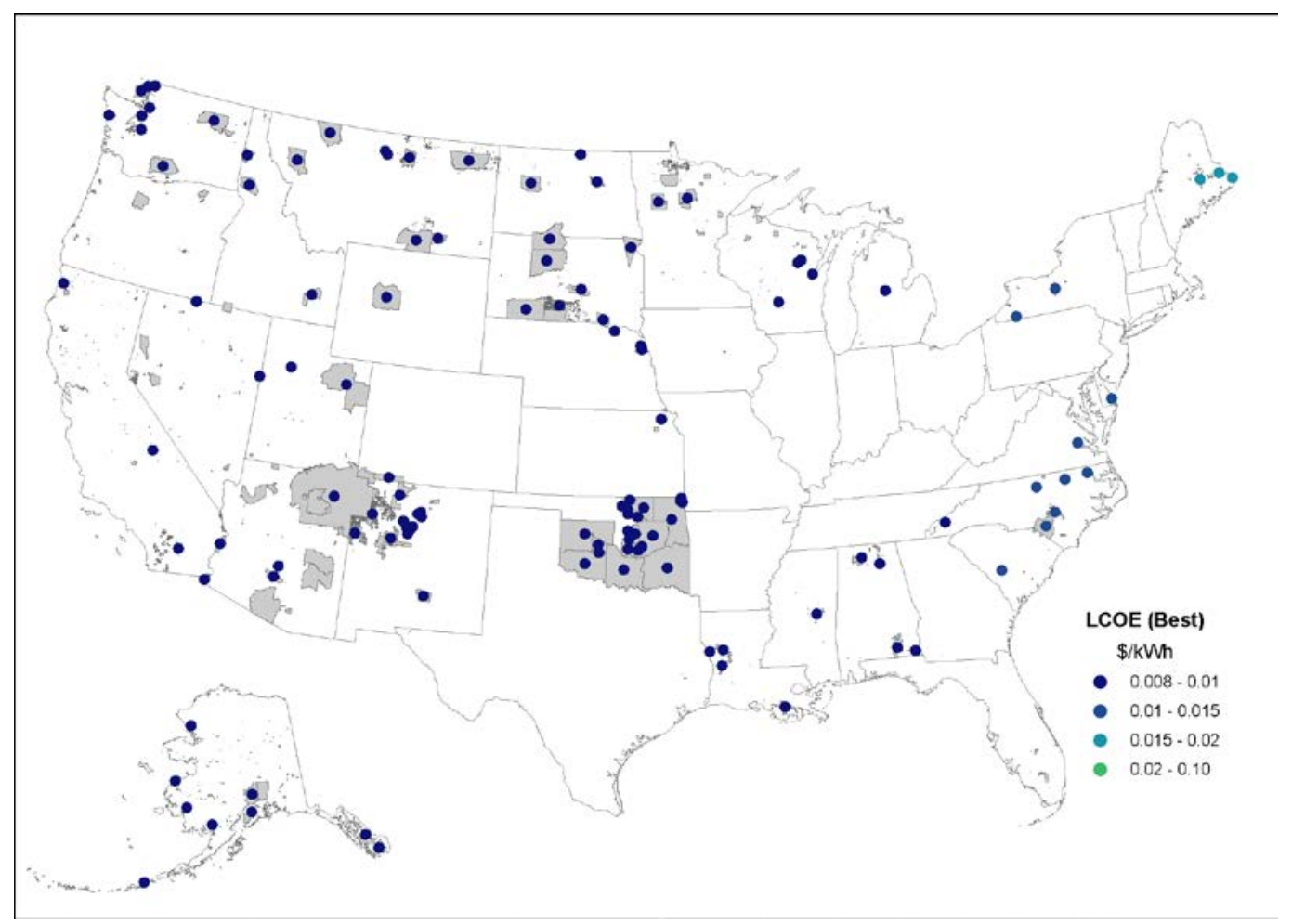

Figure 20. Potential biogas levelized cost of energy in tribal areas 


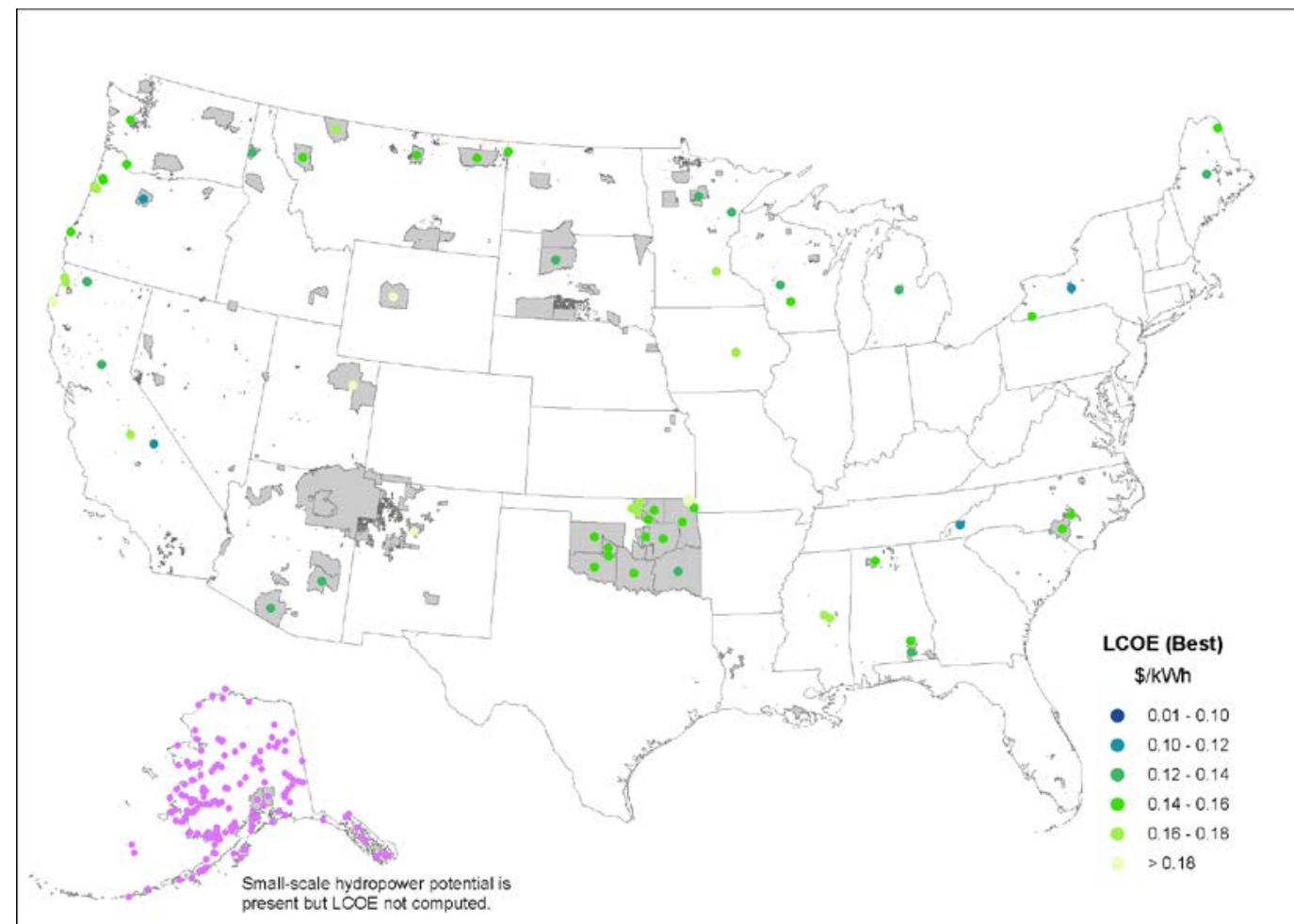

Figure 21. Potential small-scale hydropower levelized cost of energy in tribal areas 


\section{Conclusions}

This study estimates the technical and economic potential of renewable energy technologies on tribal lands. Table 23 and Table 24 summarize the results of the utility-scale technical potential on tribal lands within their boundaries as well as within an extended area of 10 miles, respectively. The utility-scale technical potential results are presented in terms of capacity (maximum power output measured in $\mathrm{kW}, \mathrm{MW}$, etc.) and generation (the total amount of electricity generated by a power plant over a specific period of time, e.g. kWh, MWh, etc.). The analysis shows that the utility-scale technical generation potential on tribal lands is approximately $6.5 \%$ of the total national technical generation potential. (The tribal lands compose approximately $5.8 \%$ of the land area in the contiguous United States.) The potential doubles within the expanded area considered in our model. (The expanded area is approximately $16.3 \%$ of the contiguous U.S. land area.) These estimates are for tribal lands in the contiguous 48 states; Alaska Native villages are included only in the distributed generation results.

Table 23. Utility-Scale Technical Potential on Tribal Lands in the Contiguous 48 States by Capacity and Generation

\begin{tabular}{|c|c|c|c|c|c|c|}
\hline Technology & $\begin{array}{l}\text { Tribal } \\
\text { Capacity } \\
\text { Potential } \\
\text { (GW) }\end{array}$ & $\begin{array}{l}\text { National } \\
\text { Capacity } \\
\text { Potential } \\
\text { (GW) }\end{array}$ & $\begin{array}{l}\text { National } \\
\text { Capacity } \\
\text { (\%) }\end{array}$ & $\begin{array}{l}\text { Tribal } \\
\text { Generation } \\
\text { Potential } \\
\text { (TWh) }\end{array}$ & $\begin{array}{l}\text { National } \\
\text { Generation } \\
\text { Potential } \\
\text { (TWh) }\end{array}$ & $\begin{array}{l}\text { National } \\
\text { Generation } \\
\text { (\%) }\end{array}$ \\
\hline $\begin{array}{l}\text { Utility-scale } \\
\text { PV }\end{array}$ & 6,035 & 118,918 & $5 \%$ & 10,689 & 197,087 & $5.4 \%$ \\
\hline CSP & 2,114 & 26,318 & $8 \%$ & 7,701 & 92,994 & $8.3 \%$ \\
\hline Wind & 891 & 10,119 & $8.8 \%$ & 2,394 & 30,781 & $7.8 \%$ \\
\hline $\begin{array}{l}\text { Geothermal } \\
\text { (hydrothermal) }\end{array}$ & 0.033 & 5.7 & $0.6 \%$ & 0.228 & 39 & $0.6 \%$ \\
\hline $\begin{array}{l}\text { Biomass } \\
\text { (wood) }\end{array}$ & 0.542 & 34 & $1.6 \%$ & 2 & 156 & $1.6 \%$ \\
\hline Hydropower & 21 & 62 & $34.4 \%$ & 124 & 342 & $36.4 \%$ \\
\hline Total $^{a}$ & 9,063 & 155,457 & $5.8 \%$ & 20,912 & 321,401 & $6.5 \%$ \\
\hline
\end{tabular}

${ }^{a}$ Each technology is evaluated separately; the same land area might be available for many technologies. 
Table 24. Utility-Scale Extended (Tribal Land Base Plus Adjacent 10 Miles) Technical Potential on Tribal Lands in the Contiguous 48 States by Capacity and Generation

\begin{tabular}{lllllll}
\hline & $\begin{array}{l}\text { Expanded } \\
\text { Tribal } \\
\text { Area } \\
\text { Capacity } \\
\text { Potential } \\
\text { (GW) }\end{array}$ & $\begin{array}{l}\text { National } \\
\text { Capacity } \\
\text { Potential } \\
\text { (GW) }\end{array}$ & $\begin{array}{l}\text { National } \\
\text { Capacity } \\
\text { (\%) }\end{array}$ & $\begin{array}{l}\text { Expanded } \\
\text { Tribal Area } \\
\text { Generation } \\
\text { Potential } \\
\text { (TWh) }\end{array}$ & $\begin{array}{l}\text { National } \\
\text { Generation } \\
\text { Potential } \\
\text { (TWh) }\end{array}$ & $\begin{array}{l}\text { National } \\
\text { Generation } \\
\text { (\%) }\end{array}$ \\
\hline $\begin{array}{l}\text { Utility-scale } \\
\text { PV }\end{array}$ & 13,281 & 118,918 & $11.2 \%$ & 22,736 & 197,087 & $11.5 \%$ \\
CSP & 4,012 & 26,318 & $15 \%$ & 14,703 & 92,994 & $15.8 \%$ \\
Wind & 1,816 & 10,119 & $18 \%$ & 4,940 & 30,781 & $16 \%$ \\
$\begin{array}{l}\text { Geothermal } \\
\text { (hydrothermal) }\end{array}$ & 0.508 & 5.7 & $9 \%$ & 3.5 & 39 & $9 \%$ \\
$\begin{array}{l}\text { Biomass } \\
\text { (wood) }\end{array}$ & 3.7 & 34 & $10.7 \%$ & 16.8 & 156 & $10.7 \%$ \\
$\begin{array}{l}\text { Hydropower } \\
\text { Total }\end{array}$ & 39 & 62 & $63 \%$ & 225 & 342 & $65.8 \%$ \\
\hline
\end{tabular}

${ }^{a}$ Each technology is evaluated separately; the same land area might be available for many technologies.

The results of the utility-scale economic assessment indicate a sizeable but variable potential for land-based wind and utility-scale PV. Under this analysis, the tribal economic potential for landbased wind exceeds $1 \mathrm{GW}$, which could produce more than $3 \mathrm{TWh}$ annually. For utility-scale $\mathrm{PV}$, it is more than $61 \mathrm{GW}$, which could produce nearly $116 \mathrm{TWh}$ of electricity annually. The economic potential can vary based on the input assumptions used; thus, the results of this analysis should be considered case-specific and illustrative only.

Distributed wind and PV potential exists for every tribal area, but in low-resource areas the resulting LCOE is high and might not be competitive with grid electricity prices. Many tribal lands have good biogas potential from the sources examined here (animal manure, wastewater sludge, and landfill material), and it is likely that many locations might also have high biogas potential from food waste given the number of casinos on tribal lands, especially those with large food services on-site. On a site-specific basis, distributed hydropower systems are feasible on tribal lands.

Several areas of focus for future research are worth noting here. Future technical potential analysis could benefit from higher resolution data for solar, more detailed data for hydropower, and complete biomass data for Alaska. A biogas potential analysis for food waste at casinos and other restaurant facilities would improve our understanding of this technology development potential on tribal lands and support tribes' decisions regarding alternative uses of these waste materials.

Future improvements to the economic potential assessment include incorporating both in-region and out-of-region transmission costs, environmental benefits, other policy drivers such as renewable portfolio standards, and any sensitivities to tax-oriented policies. Future work could also examine how economic competitiveness can change when future modifications to renewable 
energy costs and projections for the broader market, prices of energy, and other related factors are considered. This constantly changing cost profile is particularly important in determining the relative value of renewable energy compared to other replacement sources of energy. 


\section{References}

500 Nations. 2017. “Indian Casinos.” Accessed March 2017.

http://500nations.com/Indian_Casinos.asp\#find.

Alaska Energy Authority. 2016. Renewable Energy Atlas of Alaska: A Guide to Alaska's Clean, Local, and Inexhaustible Energy Resources. Anchorage, AK.

http://alaskarenewableenergy.org/wp-content/uploads/2016/07/RenewableEnergy-Atlas-of-

Alaska-2016April.pdf.

BioCycle Journal. 2010. “State of Garbage in America.” October 2010.

https://www.biocycle.net/2010/10/26/the-state-of-garbage-in-america-4/.

Brown, A., P. Beiter, D. Heimiller, C. Davidson, P. Denholm, J. Melius, A. Lopez, D. Hettinger, D. Mulcahy, and G. Porro. 2016. Estimating Renewable Energy Economic Potential in the

United States: Methodology and Initial Results (Technical Report NREL/TP-6A20-64503).

Golden, CO: National Renewable Energy Laboratory.

https://www.nrel.gov/docs/fy15osti/64503.pdf.

Business Insider. 2016. “American Restaurants Are Wasting an Incredible Amount of Food-

Here's the Proof.” May 2016. http://www.businessinsider.com/solving-food-waste-in-americasrestaurants-2016-5.

U.S. Department of Energy. 2016. Hydropower Vision Report. A New Chapter for America's $1^{\text {st }}$ Renewable Electricity Source (Technical Report DOE/GO-1020164869). Washington, D.C. https://energy.gov/sites/prod/files/2016/10/f33/Hydropower-Vision-10262016_0.pdf.

U.S. Department of Energy. Forthcoming. Geothermal Vision Report. Washington, D.C.

Doris, E., A. Lopez, and D. Beckley. 2013. Geospatial Analysis of Renewable Energy Technical Potential on Tribal Lands (Technical Report DOE/IE-0013). Golden, CO: National Renewable Energy Laboratory. https://www.nrel.gov/docs/fy13osti/56641.pdf.

Draxl, C., B.-M. Hodge, A. Clifton, and J. McCaa. 2015. Overview and Meteorological Validation of the Wind Integration National Dataset Toolkit (Technical Report NREL/TP-500061740). Golden, CO: National Renewable Energy Laboratory. https://www.nrel.gov/docs/fy15osti/61740.pdf.

U.S. Energy Information Administration. 2017. Annual Energy Outlook. Washington, D.C.

—. 2017a. “Energy from Moving Water.” June 2017.

https://www.eia.gov/energyexplained/index.cfm?page=hydropower_home.

—. 2017b. “U.S. Natural Gas Electric Power Price.” August 2017.

https://www.eia.gov/dnav/ng/hist/n3045us3m.htm.

U.S. Environmental Protection Agency. 2017a. “2012 Clean Watersheds Needs Survey Data.” Accessed March 2017. https://www.epa.gov/cwns. 
—. 2017b. “Landfill Methane Outreach Program: Landfill Technical Data.” March 2017. https://www.epa.gov/lmop/landfill-technical-data.

Food and Agriculture Organization of the United Nations. 2017. "Food Loss and Food Waste.” Accessed June 2017. http://www.fao.org/food-loss-and-food-waste/en/.

Fulhage, C., D. Sievers, and J. Fischer. 2017. “Generating Methane Gas from Manure.” University of Missouri Extension: Department of Agricultural Engineering. Accessed March 2017. http://extension.missouri.edu/p/G1881.

Habte, A., M. Sengupta, and A. Lopez. 2017. Evaluation of the National Solar Radiation Database (NSRDB): 1998-2015 (Technical Report NREL/TP-5D00-67722). Golden, CO: National Renewable Energy Laboratory. https://www.nrel.gov/docs/fy17osti/67722.pdf.

Hadjerioua, B., Y. Wei, and S.-C Kao. 2012. An Assessment of Energy Potential At NonPowered Dams In The United States. Washington, D.C. http://nhaap.ornl.gov/sites/default/files/NHAAP_NPD_FY11_Final_Report.pdf.

Homer, C.G., J.A. Dewitz, L. Yang, S. Jin, P. Danielson, G. Xian, J. Coulston, N.D. Herold, J.D. Wickham, and K. Megown. 2015. "Completion of the 2011 National Land Cover Database for the conterminous United States: Representing a Decade of Land Cover Change Information.” Photogrammetric Engineering and Remote Sensing May 81 (5): 345-

354. http://www.asprs.org/a/publications/pers/2015journals/PERS_May_2015/HTML/files/assets basic-html/index.html\#345/z\#noFlash.

Hurlbut, D., S. Haase, C. Barrows, L. Bird, G. Brinkman, J. Cook, M. Day, V. Diakov, E. Hale, D. Keyser, A. Lopez, T. Mai, J. McLaren, E. Reiter, B. Stoll, T. Tian, H. Cutler, D. Bain, and T. Acker. 2016. Navajo Generating Station and Federal Resource Planning Volume 1: Sectoral, Technical and Economic Trends (Technical Report NREL/TP-6A20-66506). Golden, CO:

National Renewable Energy Laboratory and U.S. Department of the Interior. https://www.nrel.gov/docs/fy17osti/66506.pdf

Indian Gaming. 2017. “Casinos in Indian Country.” Accessed March 2017. http://indiangaming.com/casino/.

Kao, S-C., R. McManamay, K. Stewart, N. Samu, B. Hadjerioua, S. DeNeale, D. Yeasmin, M. Fayzul, K. Pasha, A. Oubeidillah, and B. Smith. 2014. New Stream-Reach Development: A Comprehensive Assessment of Hydropower Energy Potential in the United States (Technical Report). Oak Ridge, TN: Oak Ridge National Laboratory. http://nhaap.ornl.gov/sites/default/files/ORNL_NSD_FY14_Final_Report.pdf.

Lopez, A., B. Roberts, D. Heimiller, N. Blair, and G. Porro. 2012. U.S. Renewable Energy Technical Potentials: A GIS-Based Analysis (Technical Report NREL/TP-6A20-51946). Golden, CO: National Renewable Energy Laboratory. https://www.nrel.gov/docs/fy12osti/51946.pdf.

Mills, A., and R. Wiser. 2012. Changes in the Economic Value of Variable Generation at High Penetration Levels: A Pilot Case Study in California (Technical Report LBNL-5445E). 
Berkeley, CA: Lawrence Berkeley National Laboratory. https:/emp.lbl.gov/sites/all/files/lbnl$\underline{5445 e . p d f}$

National Indian Gaming Commission. 2017. "Gaming Tribe Report (Sorted by State).” https://www.nigc.gov/images/uploads/state.pdf.

National Renewable Energy Laboratory. 2016. "Distributed Generation Renewable Energy Estimate of Costs.” https://www.nrel.gov/analysis/tech-lcoe-re-cost-est.html.

— . 2017. NREL Annual Technology Baseline (ATB). Golden, CO. https://atb.nrel.gov/.

Orrell, A., N. Foster, S. Morris, and J. Homer. 2017. 2016 Distributed Wind Market Report (Technical Report). Richland, WA: Pacific Northwest National Laboratory.

Patel, N. 2012. "Distributed Biomass Waste-to-Energy Technology for a Sustainable Future.” Biomass Magazine. April 2012. http://biomassmagazine.com/articles/6228/distributed-biomasswaste-to-energy-technology-for-a-sustainable-future.

U.S. Census Bureau. 2012. "County Business Patterns 2012 Data.” https://www.census.gov/programs-surveys/cbp.html.

—. 2016. "American Indian Areas, Alaska Native Areas, and Hawaii Homelands Boundary File.” https://www.census.gov/geo/maps-data/data/cbf/cbf_aiannh.html.

Milbrandt, A., T. Seiple, D. Heimiller, A. Coleman, and R. Skaggs. 2018. "Wet Waste-to-Energy Resource Assessment.” Forthcoming.

Saur, G., and A. Milbrandt. 2014. Renewable Hydrogen Potential from Biogas in the United States (Technical Report NREL/TP-5400-60283). Golden, CO: National Renewable Energy Laboratory. https://www.nrel.gov/docs/fy14osti/60283.pdf.

U.S. Forest Service. 2011. Forests of Southeast and South-Central Alaska, 2004-2008: FiveYear Forest Inventory and Analysis Report. Portland, OR. https://www.fs.fed.us/pnw/rma/fiatopics/publications/documents/AK_pnw_gtr835.pdf.

U.S. Forest Service. 2012. “Timber Product Output Database.”

University of Colorado Boulder. 2017. "Latent Semantic Analysis. Geothermal.” Accessed July 2017. http://lsa.colorado.edu/essence/texts/geothermal.html.

Warner, E., K. Moriarty, J. Lewis, A. Milbrandt, and A. Schwab. 2017. Bioenergy Market Report (Technical Report DOE/GO-102017-4905). Golden, CO: National Renewable Energy Laboratory. https://www.nrel.gov/docs/fy17osti/66995.pdf.

Williams, C.F., M.J. Reed, R.H. Mariner, J. DeAngelo, P.S. Galanis, Jr. 2008. “Assessment of Moderate- and High-Temperature Geothermal Resources of the United States.” U.S. Geological Survey Fact Sheet 2008-3082. https://pubs.usgs.gov/fs/2008/3082/pdf/fs2008-3082.pdf. 
Wiser, R., and M. Bolinger. 2017. 2016 Wind Technologies Market Report (Technical Report). Berkeley, CA: Lawrence Berkeley National Laboratory.

http://www.osti.gov/scitech/servlets/purl/1393638. 


\section{Appendix A: Technology-Specific Exclusions and Constraints}

Table A-1. Utility-Scale Wind (Land-Based Only)

\begin{tabular}{|c|c|}
\hline Exclusion/Constraint & Data Source \\
\hline $\begin{array}{l}\text { Exclude } 100 \% \text { of land areas with slope } \\
>20 \%\end{array}$ & $\begin{array}{l}\text { U.S. Geological Survey Shuttle Radar Topography } \\
\text { Mission } 90 \mathrm{~m} \mathrm{(2016)}\end{array}$ \\
\hline \multirow{3}{*}{$\begin{array}{l}\text { Exclude } 100 \% \text { of federal lands designated } \\
\text { as a park, wilderness, wilderness study } \\
\text { area, national monument, national } \\
\text { battlefield, recreation area, national } \\
\text { conservation area, wildlife refuge, wildlife } \\
\text { area, wild and scenic river, or inventoried } \\
\text { roadless area }\end{array}$} & U.S. Geological Survey Federal Lands (2015) \\
\hline & U.S. Forest Service Inventoried Roadless Areas (2014) \\
\hline & $\begin{array}{l}\text { U.S. Bureau of Land Management Areas of Critical } \\
\text { Environmental Concern (2014) }\end{array}$ \\
\hline \multirow{3}{*}{$\begin{array}{l}\text { Exclude } 100 \% \text { of incompatible land use } \\
\text { areas: urban areas, airports, wetlands, } \\
\text { and water bodies }\end{array}$} & $\begin{array}{l}\text { U.S. Geological Survey National Land Cover Database } \\
\text { (2011) }\end{array}$ \\
\hline & $\begin{array}{l}\text { U.S. Department of Homeland Security, Homeland } \\
\text { Security Infrastructure Program Gold-Airports (2012) }\end{array}$ \\
\hline & ESRI/U.S. Geological Survey USA Urban Extents (2012) \\
\hline \multirow[t]{2}{*}{$\begin{array}{l}\text { Exclude } 50 \% \text { of areas characterized as } \\
\text { non-ridgecrest forested land }\end{array}$} & $\begin{array}{l}\text { U.S. Geological Survey Shuttle Radar Topography } \\
\text { Mission } 90 \mathrm{~m}(2016)\end{array}$ \\
\hline & $\begin{array}{l}\text { U.S. Geological Survey National Land Cover Database } \\
\text { (2011) }\end{array}$ \\
\hline
\end{tabular}

Table A-2. Utility-Scale Photovoltaics

\begin{tabular}{|c|c|}
\hline Exclusion/Constraint & Data Source \\
\hline $\begin{array}{l}\text { Exclude } 100 \% \text { of land areas with slope } \\
>5 \%\end{array}$ & $\begin{array}{l}\text { U.S. Geological Survey Shuttle Radar Topography } \\
\text { Mission } 90 \mathrm{~m}(2016)\end{array}$ \\
\hline $\begin{array}{l}\text { Exclude } 100 \% \text { of federal lands designated } \\
\text { as a park, wilderness, wilderness study } \\
\text { area, national monument, national } \\
\text { battlefield, recreation area, national } \\
\text { conservation area, wildlife refuge, wildlife } \\
\text { area, wild and scenic river, or inventoried } \\
\text { roadless area }\end{array}$ & $\begin{array}{l}\text { U.S. Geological Survey Federal Lands (2015) } \\
\text { U.S. Forest Service Inventoried Roadless Areas (2014) } \\
\text { U.S. Bureau of Land Management Areas of Critical } \\
\text { Environmental Concern (2014) }\end{array}$ \\
\hline $\begin{array}{l}\text { Exclude } 100 \% \text { of incompatible land use } \\
\text { areas: wetlands and water bodies }\end{array}$ & $\begin{array}{l}\text { U.S. Geological Survey National Land Cover Database } \\
\text { (2011) }\end{array}$ \\
\hline $\begin{array}{l}\text { Exclude remaining areas with }<1 \mathrm{~km}^{2} \text { in } \\
\text { contiguous area }\end{array}$ & NREL Analysis \\
\hline
\end{tabular}


Table A-3. Concentrating Solar Power

\begin{tabular}{|c|c|}
\hline Exclusion/Constraint & Data Source \\
\hline $\begin{array}{l}\text { Exclude } 100 \% \text { of land areas with slope } \\
>3 \%\end{array}$ & $\begin{array}{l}\text { U.S. Geological Survey Shuttle Radar Topography } \\
\text { Mission } 90 \mathrm{~m}(2016)\end{array}$ \\
\hline $\begin{array}{l}\text { Exclude } 100 \% \text { of federal lands designated } \\
\text { as a park, wilderness, wilderness study } \\
\text { area, national monument, national } \\
\text { battlefield, recreation area, national } \\
\text { conservation area, wildlife refuge, wildlife } \\
\text { area, wild and scenic river, or inventoried } \\
\text { roadless area }\end{array}$ & $\begin{array}{l}\text { U.S. Geological Survey Federal Lands (2015) } \\
\text { U.S. Forest Service Inventoried Roadless Areas (2014) } \\
\text { U.S. Bureau of Land Management Areas of Critical } \\
\text { Environmental Concern (2014) }\end{array}$ \\
\hline $\begin{array}{l}\text { Exclude } 100 \% \text { of incompatible land use } \\
\text { areas: urban, wetlands, and water bodies }\end{array}$ & $\begin{array}{l}\text { U.S. Geological Survey National Land Cover Database } \\
(2011) \\
\text { ESRI/U.S. Geological Survey USA Urban Extents (2009) }\end{array}$ \\
\hline $\begin{array}{l}\text { Exclude remaining areas with }<1 \mathrm{~km}^{2} \text { in } \\
\text { contiguous area }\end{array}$ & NREL Analysis \\
\hline
\end{tabular}




\section{Appendix B: Tribal Energy Atlas}

This study serves as a reference for the renewable energy resource potential data used in the Tribal Energy Atlas available at https://maps.nrel.gov/tribal-energy-atlas. The Atlas is an interactive geospatial application that allows users to view resource, infrastructure, demographic, and other relevant information, as well as query the data and perform simple analyses.

NREL used the data collected and modeled in this study, along with other relevant information on infrastructure (e.g., conventional and renewable energy facilities, transmission lines, railroads), environment (e.g., water availability, protected areas), energy efficiency, electricity and natural gas prices, and more, to populate the Tribal Energy Atlas. The data is not limited to renewable energy, and also includes natural gas, petroleum, and other conventional energy sources.

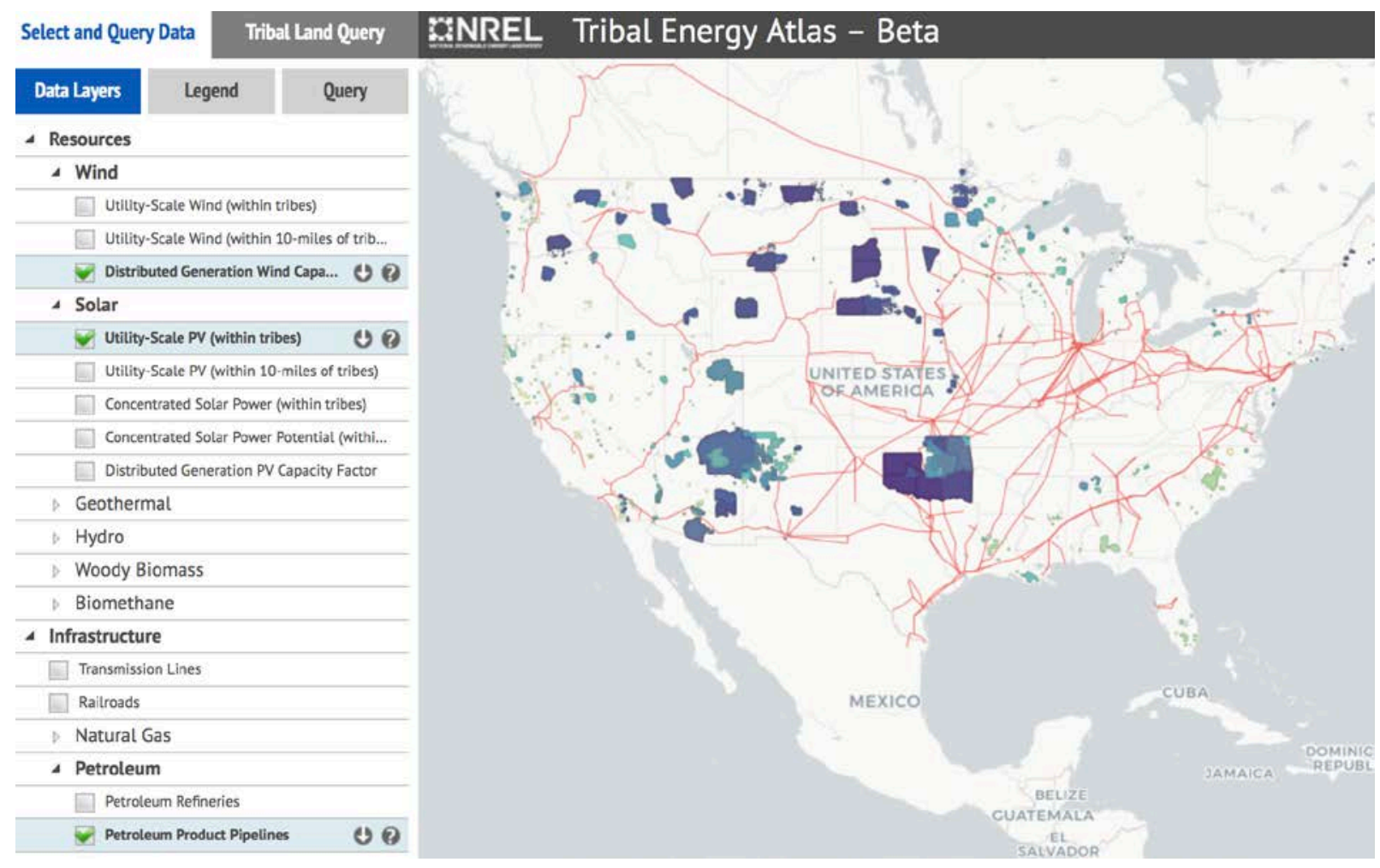

Screenshot of the interactive Tribal Energy Atlas tool.

The Atlas incorporates functionality that enables users to view resource, infrastructure, and other relevant data about specific tribal lands. It was designed to be highly intuitive, so users do not need prior geospatial experience to use it. The tool also incorporates functionality that enables users to query data, conduct simple analyses that provide demographic, installed capacity, and utility-scale renewable energy technical potential summaries, and download data. 